\section{A) Check for updates}

Cite this: Dalton Trans., 2021, 50 4380

Received 5th January 2021,

Accepted 26th February 2021

DOI: $10.1039 / \mathrm{d} 1 \mathrm{dt} 00038 \mathrm{a}$

rsc.li/dalton

\title{
Synthesis, properties and structural features of molybdenum(v) oxide trichloride complexes with neutral chalcogenoether ligands $\uparrow$
}

\begin{abstract}
Danielle E. Smith, William Levason, (D) James Powell (D) and Gillian Reid (DD*
Complexes of oxotrichloromolybdenum(v) with neutral group 16 donor ligands, $\left[\mathrm{MoOCl}_{3}(\mathrm{~L}-\mathrm{L})\right](\mathrm{L}-\mathrm{L}=\mathrm{RS}$ $\left.\left(\mathrm{CH}_{2}\right)_{2} \mathrm{SR}, \mathrm{R}={ }^{\mathrm{i}} \mathrm{Pr}, \mathrm{Ph} ; \mathrm{MeS}\left(\mathrm{CH}_{2}\right)_{3} \mathrm{SMe} ; \mathrm{MeSe}\left(\mathrm{CH}_{2}\right)_{2} \mathrm{SeMe} ; \mathrm{MeSe}\left(\mathrm{CH}_{2}\right)_{3} \mathrm{SeMe}\right)$, [ $\left.\left\{\mathrm{MOOCl}_{2}\left(\mathrm{EMe}_{2}\right)\right\}_{2}(\mu-\mathrm{Cl})_{2}\right](\mathrm{E}=$ $\mathrm{S}, \mathrm{Se}, \mathrm{Te}),\left[\left(\mathrm{MoOCl}_{3}\right)_{2}\left\{\mathrm{O}-\mathrm{C}_{6} \mathrm{H}_{4}(\mathrm{EMe})_{2}\right\}\right]_{n}\left(\mathrm{E}=\mathrm{Se}\right.$ or Te) and $\left[\left(\mathrm{MoOCl}_{3}\right)_{2}\left\{\mathrm{MeTe}\left(\mathrm{CH}_{2}\right)_{3} \mathrm{TeMe}\right\}\right]_{n}$, have been obtained by reaction of the ligands with $\left[\mathrm{MoOCl}_{3}(\text { thf })_{2}\right]$ or $\mathrm{MoOCl}_{3}$ in either $\mathrm{CH}_{2} \mathrm{Cl}_{2}$ or toluene, and characterised by microanalysis, IR and UV-visible spectroscopy and magnetic measurements. The telluroethers are the first examples containing $\mathrm{Mo}$ in a positive oxidation state. X-ray crystal structures are reported for the six-coordinate fac- $\left[\mathrm{MoOCl}_{3}\left\{\mathrm{MeS}\left(\mathrm{CH}_{2}\right)_{3} \mathrm{SMe}\right\}\right]$, mer-[MoOCl$\left.{ }_{3}\left\{{ }^{i} \mathrm{PrS}\left(\mathrm{CH}_{2}\right)_{2} \mathrm{~S}^{i} \mathrm{Pr}\right\}\right]$ and mer$\left[\mathrm{MoOCl}_{3}\left\{\mathrm{MeSe}\left(\mathrm{CH}_{2}\right)_{2} \mathrm{SeMe}\right\}\right]$, as well as the six-coordinate chloride-bridged dimers, $\left[\left\{\mathrm{MoOCl}_{2}\left(\mathrm{SMe}_{2}\right)\right\}_{2}(\mu-\right.$ $\left.\mathrm{Cl})_{2}\right]$ and $\left[\left\{\mathrm{MoOCl}_{2}\left(\mathrm{SeMe}_{2}\right)\right\}_{2}(\mu-\mathrm{Cl})_{2}\right]$. The structure of the mixed-valence decomposition product, $\left[\mathrm{Mo}{ }^{\mathrm{IV}} \mathrm{Cl}\right.$ $\left.\left\{0-\mathrm{C}_{6} \mathrm{H}_{4}(\mathrm{TeMe})_{2}\right\}_{2}(\mu-\mathrm{O}) \mathrm{Mo}^{\vee} \mathrm{OCl}_{4}\right]$, was also determined. In toluene solution $\mathrm{MoOCl}_{4}$ is reduced by MeS $\left(\mathrm{CH}_{2}\right)_{3} \mathrm{SMe}$ to produce the $\mathrm{Mo}(\mathrm{v})$ complex, $\left[\mathrm{MoOCl}_{3}\left\{\mathrm{MeS}\left(\mathrm{CH}_{2}\right)_{3} \mathrm{SMe}\right\}\right]$. Crystal structures of the previously unknown diphosphine analogue, $\left[\mathrm{MoOCl}_{3}\left\{\mathrm{Me}_{2} \mathrm{P}\left(\mathrm{CH}_{2}\right)_{2} \mathrm{PMe}_{2}\right\}\right]$, and the mixed-valence derivative $\left[\mathrm{Mo}{ }^{\mathrm{IV}} \mathrm{Cl}\right.$ $\left.\left\{\mathrm{Me}_{2} \mathrm{P}\left(\mathrm{CH}_{2}\right)_{2} \mathrm{PMe}_{2}\right\}_{2}(\mu-\mathrm{O}) \mathrm{Mo}^{\vee} \mathrm{OCl}_{4}\right]$ are also reported for comparison and help to clarify earlier contradictory literature reports. In contrast to the dimeric $\mathrm{EMe}_{2}$ complexes, $\left[\left\{\mathrm{MoOCl}_{2}\left(\mathrm{EMe}_{2}\right)\right\}_{2}(\mu-\mathrm{Cl})_{2}\right], \mathrm{PMe}_{3}$ forms the monomeric complex, fac- $\left[\mathrm{MoOCl}_{3}\left(\mathrm{PMe}_{3}\right)_{2}\right]$.
\end{abstract}

\section{Introduction}

The coordination chemistry of high oxidation state molybdenum halides and oxide halides was first explored in some detail in the 1970's, with the emphasis on neutral $\mathrm{N}$ - and O-donor ligands ${ }^{1-4}$ and with much of the impetus coming from modelling of the metal sites in molybdenum enzymes and applications in catalysis. ${ }^{4-6}$ Interest in high oxidation molybdenum complexes bearing sulfur donor ligands stems in part from the presence of Mo-S coordination in the molybdenum-containing enzymes, nitrate reductase, sulfite oxidase and Fe-Mo nitrogenases which involve (anionic) cysteine or sulfide ligands. ${ }^{4-6}$ The chemistry with neutral P- and As-donor ligands with $\mathrm{Mo}(\mathrm{v})$ has also been investigated, ${ }^{7-11}$ but sulfur-

School of Chemistry, University of Southampton, Southampton SO17 1BJ, UK. E-mail: G.Reid@soton.ac.uk

$\dagger$ Electronic supplementary information (ESI) available: Crystallographic parameters (Table S1), IR and UV/visible spectra for the new complexes. CCDC 2050667: [\{ $\left.\left.\mathrm{MoOCl}_{2}\left(\mathrm{SeMe}_{2}\right)\right\}(\mu-\mathrm{Cl})_{2}\right]$, 2050668: [ $\left.\mathrm{MoOCl}_{3}\left(\mathrm{Me}_{2} \mathrm{P}\left(\mathrm{CH}_{2}\right)_{2} \mathrm{PMe}_{2}\right)\right]$, 2050669: $\left[\mathrm{MoOCl}_{3}\left(\mathrm{PhS}\left(\mathrm{CH}_{2}\right)_{2} \mathrm{SPh}\right)\right]$, 2050670: [ $\left.\mathrm{MoOCl}_{3}\left(\mathrm{MeSe}\left(\mathrm{CH}_{2}\right)_{2} \mathrm{SeMe}\right)\right]$, 2050671: $\left[\mathrm{MoOCl}_{3}\left({ }^{\mathrm{i}} \mathrm{PrS}\left(\mathrm{CH}_{2}\right)_{2} \mathrm{~S}^{\mathrm{i}} \mathrm{Pr}\right)\right], 2050672:\left[\left\{\mathrm{MoOCl}_{2}\left(\mathrm{SMe}_{2}\right)\right\}(\mu-\mathrm{Cl})_{2}\right], 2050673$ :

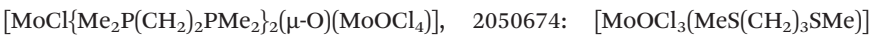
2050891: $\left[\mathrm{MoCl}\left\{0-\mathrm{C}_{6} \mathrm{H}_{4}(\mathrm{TeMe})_{2}\right\}_{2}(\mu-\mathrm{O}) \mathrm{MoOCl}_{4}\right] \cdot \mathrm{CH}_{2} \mathrm{Cl}_{2}$. For ESI and crystallographic data in CIF or other electronic format see DOI: 10.1039/d1dt00038a based ligands were mostly represented by charged thiolate and dithiocarbamate ligands..$^{2-4}$ More recent work has reported a series of extremely moisture sensitive $\mathrm{Mo}(\mathrm{vI})$ complexes $\left[\mathrm{MoO}_{2} \mathrm{X}_{2}\right.$ (dithioether) $]\left(\mathrm{X}=\mathrm{Cl}\right.$ or Br; dithioether $=\mathrm{RS}\left(\mathrm{CH}_{2}\right)_{2} \mathrm{SR}$, $\left.\mathrm{R}=\mathrm{Me}, \mathrm{Et},{ }^{\mathrm{i}} \mathrm{Pr}\right)$, which have distorted octahedral structures with the sulfur donor atoms trans to $\mathrm{Mo}=\mathrm{O} ;{ }^{12,13}$ there are also some thia-macrocyclic analogues. ${ }^{14,15}$ Complexes of the type $\left[\mathrm{MoOCl}_{3}\right.$ (dithioether)] were briefly described in the 1970's, characterised only by microanalysis and IR spectroscopy, but the structures and isomer(s) present were not established. ${ }^{15,16}$ There is a single preliminary report of a selenoether complex of $\mathrm{MoOCl}_{3},{ }^{17}$ but no known telluroether complexes.

We have recently examined the complexes of $\mathrm{WOCl}_{4}$, $\mathrm{WOCl}_{3}, \mathrm{WSCl}_{4}$ and $\mathrm{WSCl}_{3}$ with mono- and di-thio- and -seleno-ethers, and found that $\mathrm{W}(\mathrm{vI})$ or $\mathrm{W}(\mathrm{v})$ complexes could be isolated depending upon the reaction conditions. We also showed that selected dithioether complexes, for example $\left[\left(\mathrm{WSCl}_{4}\right)_{2}\left(\mu-{ }^{\mathrm{i}} \mathrm{PrSCH}_{2} \mathrm{CH}_{2} \mathrm{~S} \mathrm{Pr}\right)\right]$, can function as single source LPCVD (low pressure chemical vapour deposition) reagents for the growth of thin films of $\mathrm{WS}_{2}$, an important semiconducting material. ${ }^{18}$ In contrast, very little data on the molybdenum chalcogenide halides or their coordination complexes exists. ${ }^{19}$ The crystal structures of two forms of $\mathrm{MoSCl}_{3}$ obtained from crystals grown at high temperature found that both contain 
$\mathrm{Mo}(\mathrm{IV})$ as $\mathrm{Mo}_{2}$ units and disulfide groups, and not $\mathrm{Mo}(\mathrm{v}){ }^{20}$ It is unclear if $\mathrm{MoSCl}_{3}$ prepared at low temperatures from $\mathrm{MoCl}_{5}$ and $\mathrm{S}\left(\mathrm{SiMe}_{3}\right)_{2}$ or $\mathrm{Sb}_{2} \mathrm{~S}_{3}$ contains $\mathrm{Mo}(\mathrm{v}),{ }^{21,22}$ while $\mathrm{MoSCl}_{4}$ is unknown. ${ }^{19}$

In order to allow comparisons with the $\mathrm{WOCl}_{4}, \mathrm{WOCl}_{3}$, $\mathrm{WSCl}_{4}$ and $\mathrm{WSCl}_{3}$ chemistry, we have examined the chemistry of $\mathrm{MoOCl}_{3}$ with neutral chalcogenoethers and report here complexes of mono- and bi-dentate thio-, seleno- and telluroethers. Data on diphosphine analogues, which clarifies some of the (inconsistent) earlier studies, ${ }^{7-9}$ is also presented.

\section{Results and discussion}

Scheme 1 shows the range of chalcogenoether complexes of $\mathrm{Mo}(\mathrm{v})$ prepared in this study and the different structure types observed.

\section{Dithio- and diseleno-ether complexes}

The reaction of $\left[\mathrm{MoOCl}_{3}(\text { thf })_{2}\right]$ with $\mathrm{MeS}\left(\mathrm{CH}_{2}\right)_{3} \mathrm{SMe}$ or ${ }^{\mathrm{i}} \mathrm{PrS}$ $\left(\mathrm{CH}_{2}\right)_{2} \mathrm{~S}^{\mathrm{i}} \mathrm{Pr}$ in dry $\mathrm{CH}_{2} \mathrm{Cl}_{2}$ produced moisture sensitive. green $\left[\mathrm{MoOCl}_{3}\right.$ (dithioether)] complexes. Structures of both species were determined and revealed that $\left[\mathrm{MoOCl}_{3}\left\{\mathrm{MeS}\left(\mathrm{CH}_{2}\right)_{3} \mathrm{SMe}\right\}\right]$ (six-membered chelate ring) was the fac isomer, whilst
$\left[\mathrm{MoOCl}_{3}\left\{{ }^{\mathrm{i}} \mathrm{PrS}\left(\mathrm{CH}_{2}\right)_{2} \mathrm{~S}^{\mathrm{i}} \mathrm{Pr}\right\}\right]$ (five-membered chelate ring) was the mer-isomer (Fig. 1). The reason for the different isomers with the five- and six-membered rings is uncertain, although the difference in the S-Mo-S chelate angles of $\sim 20^{\circ}$ is notable. The behaviour replicates that found with the tungsten(v) analogues, fac-[WOCl $\left.{ }_{3}\left\{\mathrm{MeS}\left(\mathrm{CH}_{2}\right)_{3} \mathrm{SMe}\right\}\right]$ and mer-[WOCl${ }_{3}\{\mathrm{MeS}$ $\left.\left.\left(\mathrm{CH}_{2}\right)_{2} \mathrm{SMe}\right\}\right]{ }^{18}$ The bond lengths within the two structures show the expected short $\mathrm{Mo}=\mathrm{O}$ of $\sim 1.67 \AA$ and that the $\mathrm{Mo}-\mathrm{Cl}$ and $\mathrm{Mo}-\mathrm{S}$ trans to $\mathrm{Mo}=\mathrm{O}$ are longer than the other bonds of each type, indicating the high trans-influence of the $\mathrm{Mo}=\mathrm{O}$ bond.

The reaction of $\mathrm{MoOCl}_{4}$ with $\mathrm{MeS}\left(\mathrm{CH}_{2}\right)_{3}$ SMe in dry toluene gave a green product with an identical IR spectrum to that of mer-[ $\left.\mathrm{MoOCl}_{3}\left\{\mathrm{MeS}\left(\mathrm{CH}_{2}\right)_{3} \mathrm{SMe}\right\}\right]$ and the X-ray structure determination of a crystal obtained from the $\mathrm{MoOCl}_{4}$ synthesis route (Method 2) indeed confirmed it to be the Mo(v) complex. The structural data were identical to that in Table $\mathrm{S} 1, \dagger$ and hence are not reported, but confirm that thioether ligands reduce $\mathrm{MoOCl}_{4}$ to $\mathrm{MoOCl}_{3}$ complexes, similar to the behaviour reported with some $\mathrm{O}$ - and $\mathrm{N}$-donor ligands. ${ }^{23}$

The weaker $\sigma$-donor $\mathrm{PhS}\left(\mathrm{CH}_{2}\right)_{2} \mathrm{SPh}$ failed to displace the thf from $\left[\mathrm{MoOCl}_{3}(\text { thf })_{2}\right]$, but it reacted with a suspension of $\mathrm{MoOCl}_{3}$ in $\mathrm{CH}_{2} \mathrm{Cl}_{2}$ to form brown [ $\left.\mathrm{MoOCl}_{3}\left\{\mathrm{PhS}\left(\mathrm{CH}_{2}\right)_{2} \mathrm{SPh}\right\}\right]$. The crystal structure of this complex showed it to be the mer-

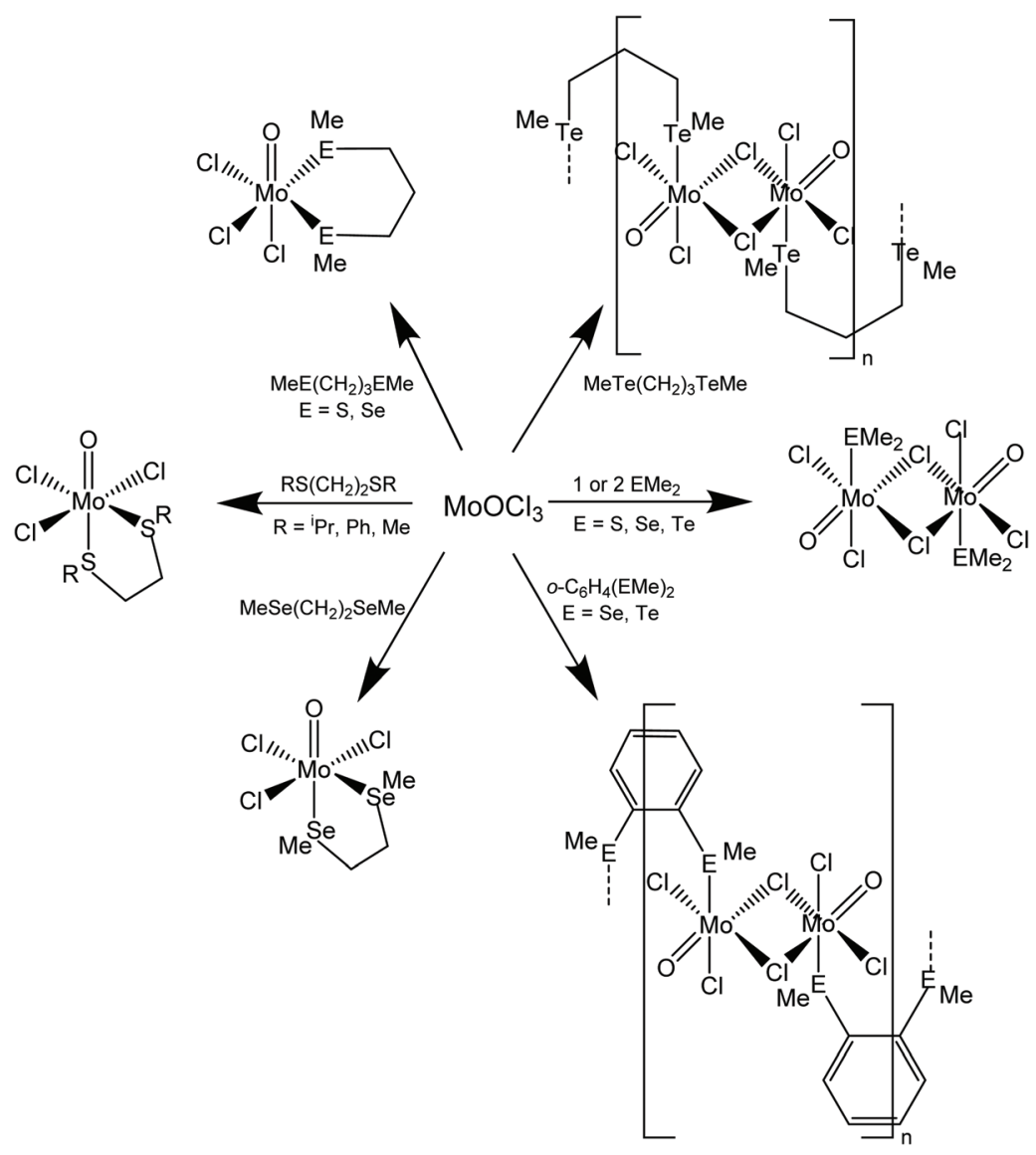

Scheme 1 Methods for the synthesis of the $\mathrm{Mo}(\mathrm{v})$ chalcogenoether complexes obtained from $\mathrm{MoOCl}_{3}$. Note that for some of the alkyl-substituted dithioether and diselenoether complexes $\left[\mathrm{MoOCl}_{3}(\mathrm{thf})_{2}\right]$ was used as the $\mathrm{Mo}(\mathrm{v})$ source - see discussion below and Experimental. 


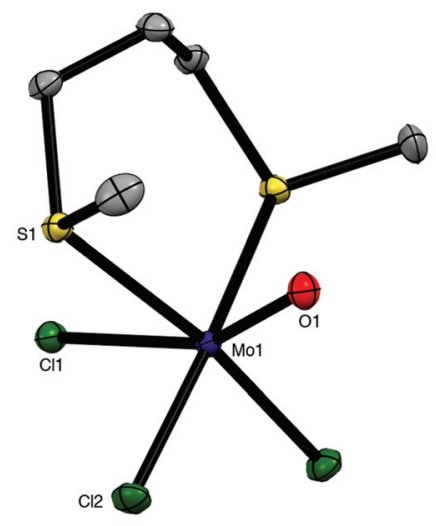

(a)

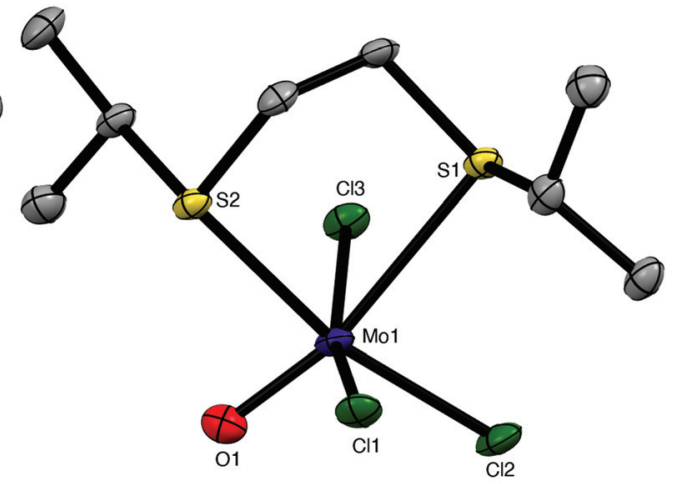

(b)

Fig. 1 Crystal structures of fac- $\left[\mathrm{MoOCl}\left\{\mathrm{MeS}_{3}\left(\mathrm{CH}_{2}\right)_{3} \mathrm{SMe}\right\}\right]$ (a) and mer-[MoOCl$\left.{ }_{3}\left\{\mathrm{PrS}\left(\mathrm{CH}_{2}\right)_{2} \mathrm{~S}^{\mathrm{i} P r}\right\}\right]$ (b) showing the atom numbering scheme. Ellipsoids are shown at 50\% probability, hydrogen atoms omitted for clarity. Selected bond lengths $(\AA)$ and angles $\left({ }^{\circ}\right)$ : (a) $\mathrm{Mo1}-\mathrm{Cl} 1=2.4540(2), \mathrm{Mo} 1-\mathrm{Cl} 2=$ $2.3451(2), \mathrm{Mo1}-\mathrm{Cl} 3=2.3451(4), \mathrm{Mo1}-\mathrm{O} 1=1.674(1), \mathrm{Mo1}-\mathrm{S} 1=2.5388(3), \mathrm{Cl} 1-\mathrm{Mo1}-\mathrm{Cl} 2=94.52(2), \mathrm{Cl} 2-\mathrm{Mo1}-\mathrm{Cl} 3=92.55(3), \mathrm{Cl} 2-\mathrm{Mo1}-\mathrm{O} 1=$ 101.87(4), $\mathrm{Cl} 3-\mathrm{Mo1}-\mathrm{O} 1=101.87(4), \mathrm{S} 1-\mathrm{Mo1}-\mathrm{S} 1=97.95(2) ;(\mathrm{b}) \mathrm{Mo1}-\mathrm{Cl} 1=2.3578(8), \mathrm{Mo1}-\mathrm{Cl} 2=2.3378(8), \mathrm{Mo1}-\mathrm{Cl} 3=2.3618(7), \mathrm{Mo1}-\mathrm{O} 1=$ 1.671(2), Mo1-S1 = 2.8298(8), Mo1-S2 = 2.5665(7), Cl1-Mo1-Cl2 = 91.25(3), Cl1-Mo1-O1 = 98.99(8), Cl1-Mo1-Cl3 = 89.69(3), Cl2-Mo1-O1 = 98.99(8), S1-Mo1-S2 = 78.83(2).

isomer (Fig. 2), which suggests that the ability to form a fivemembered chelate ring with a smaller chelate angle (S1-Mo1$\left.\mathrm{S} 2=78.55(3)^{\circ}\right)$ may be an important factor influencing the isomer formed. The structure also reveals a very markedly longer $\mathrm{Mo}-\mathrm{S}_{\text {trans }}=2.911(1) \AA$, which compares with $\mathrm{Mo}^{-}$ $\mathrm{S}_{\text {transCl }}=2.531(1) \AA$, showing the high trans-influence of the $\mathrm{Mo}=\mathrm{O}$ bond on the weaker aryl thioether donor ligand.

Brownish diselenoether complexes, $\left[\mathrm{MoOCl}_{3}\right.$ (diselenoether)] (diselenoether $\left.=\operatorname{MeSe}\left(\mathrm{CH}_{2}\right)_{2} \mathrm{SeMe}, \operatorname{MeSe}\left(\mathrm{CH}_{2}\right)_{3} \mathrm{SeMe}\right)$, were obtained from reaction of the ligands with $\mathrm{MoOCl}_{3}$ or

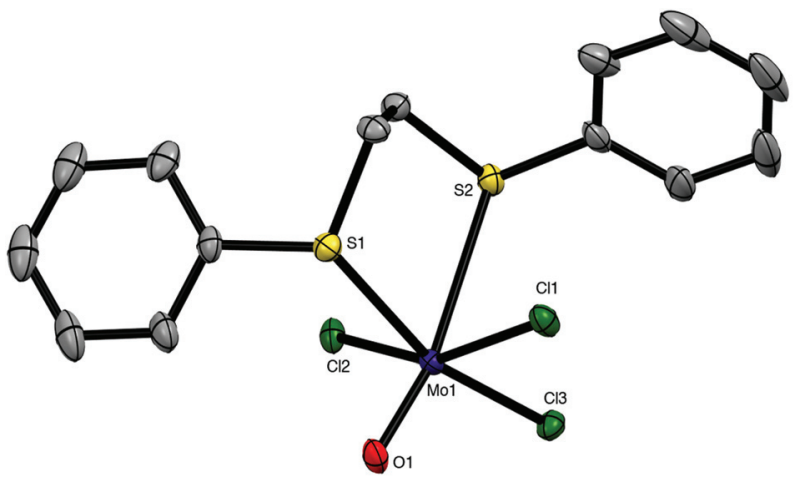

Fig. 2 Crystal structure of mer- $\left[\mathrm{MoOCl}_{3}\left\{\mathrm{PhS}\left(\mathrm{CH}_{2}\right)_{2} \mathrm{SPh}\right\}\right]$ showing the atom numbering scheme. Ellipsoids are shown at $50 \%$ probability and hydrogen atoms are omitted for clarity. Note that the $\mathrm{O} / \mathrm{Cl}$ exhibited disorder, which was modelled with split atom sites, refined to occupancies of $0.53: 0.47$. Only the major form is shown. Selected bond lengths ( $\AA$ ) and angles $\left({ }^{\circ}\right)$ : Mo1-Cl1 = 2.324(1), Mo1-Cl2 = 2.394(1), Mo1- $\mathrm{Cl} 3=$ 2.311(3), Mo1-O1 = 1.706(2), Mo1-S1 = 2.531(1), Mo1-S2 = 2.911(1), $\mathrm{Cl1}-\mathrm{Mo1}-\mathrm{Cl} 3=89.93(7), \mathrm{Cl} 1-\mathrm{Mo1}-\mathrm{O} 1=102.2(5), \mathrm{O} 1-\mathrm{Mo1}-\mathrm{Cl} 2=$ 101.1(5), O1-Mo1-Cl3 = 106.6(3), Cl2-Mo1-Cl3 = 91.28(7), Cl2-Mo1$\mathrm{S} 1=88.39(4), \mathrm{Cl} 1-\mathrm{Mo1}-\mathrm{S} 2=81.49(4), \mathrm{S} 1-\mathrm{Mo1}-\mathrm{S} 2=78.55(3)$.
$\left[\mathrm{MoOCl}_{3}(\text { thf })_{2}\right]$ in a 1:1 molar ratio, but $o-\mathrm{C}_{6} \mathrm{H}_{4}(\mathrm{SeMe})_{2}$ did not displace thf from $\left[\mathrm{MoOCl}_{3}(\mathrm{thf})_{2}\right]$. The reaction of $\mathrm{MeSeCH}_{2} \mathrm{SeMe}$ with $\mathrm{MoOCl}_{3}$ produced a black oily decomposition product. However, the 1:1 reaction of $o-\mathrm{C}_{6} \mathrm{H}_{4}(\mathrm{SeMe})_{2}$ with $\mathrm{MoOCl}_{3}$ in $\mathrm{CH}_{2} \mathrm{Cl}_{2}$ gave a brown product for which the microanalytical data indicated a $2: 1 \mathrm{MoOCl}_{3}$ : diselenoether stoichiometry. This is discussed along with the similar ditelluroether complexes below. The X-ray crystal structure of $m e r-\left[\mathrm{MoOCl}_{3}\{\mathrm{MeSe}\right.$ $\left.\left.\left(\mathrm{CH}_{2}\right)_{2} \mathrm{SeMe}\right\}\right]$ was obtained (Fig. 3).

The five complexes described have room temperature magnetic moments of $\sim 1.7$ B.M., similar to other $\mathrm{MoOCl}_{3}$ complexes, ${ }^{1,2,8,9}$ and close to the spin-only value expected for a

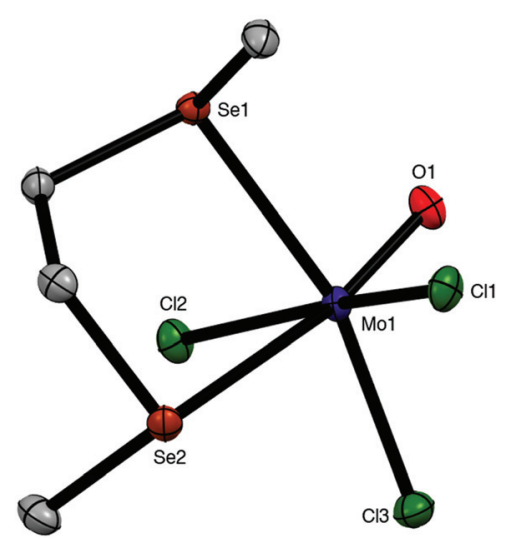

Fig. 3 Crystal structure of mer- $\left[\mathrm{MoOCl}_{3}\left\{\mathrm{MeSe}\left(\mathrm{CH}_{2}\right)_{2} \mathrm{SeMe}\right\}\right]$ showing the atom numbering scheme. Ellipsoids are shown at $50 \%$ probability and hydrogen atoms are omitted for clarity. Selected bond lengths ( $\AA$ ) and angles $\left({ }^{\circ}\right)$ : $\mathrm{Mo1}-\mathrm{Cl} 1=2.3553(5), \mathrm{Mo1}-\mathrm{Cl} 2=2.3517(5), \mathrm{Mo1}-\mathrm{Cl} 3=$ 2.3453(5), Mo1-O1 = 1.673(1), Mo1-Se1 = 2.6564(2), Mo1-Se2 = 2.8937(3), $\mathrm{Cl} 1-\mathrm{Mo1}-\mathrm{Cl} 3=90.35(2), \mathrm{Cl} 1--\mathrm{Mo1}-\mathrm{O} 1=98.98(5), \mathrm{Cl} 2-\mathrm{Mo1}-\mathrm{Cl}=$ 90.65(2), Cl3-Mo1-O1 = 107.36(5), Se1-Mo1-Se2 = 79.76(1). 
$\mathrm{d}^{1}$ complex. This indicates that any orbital contribution is quenched by the very asymmetric field of the molybdenum environment. $^{24}$ The IR spectra show very strong single bands due to $\nu(\mathrm{Mo}=\mathrm{O})$ in the range $950-980 \mathrm{~cm}^{-1}$, as well as strong overlapping bands at $355-300 \mathrm{~cm}^{-1}$ assigned as Mo-Cl modes, but do not appear to readily distinguish the isomer present. The UV/visible spectra of the solids show a clear band at 13 000-14000 $\mathrm{cm}^{-1}$ and a second band or shoulder at $\sim 19000-21000 \mathrm{~cm}^{-1}$. Assuming $C_{4 \mathrm{v}}$ symmetry (the actual metal centre symmetry is lower) and placing $\mathrm{Mo}=\mathrm{O}$ as the dominant contribution along the four-fold axis, leads to the assignment as the $\mathrm{d}-\mathrm{d}$ bands as ${ }^{2} \mathrm{~B}_{2} \rightarrow{ }^{2} \mathrm{E}$ and ${ }^{2} \mathrm{~B}_{2} \rightarrow{ }^{2} \mathrm{~B}_{1}$, respectively. ${ }^{25}$ The intense absorptions $>20000 \mathrm{~cm}^{-1}$, assigned as charge transfer bands, are less clearly resolved, but based upon the usual ligand electronegativities, ${ }^{25}$ we assign the first intense feature $\left(\sim 21000-22000 \mathrm{~cm}^{-1}\right)$ as $\mathrm{S} / \mathrm{Se}(\pi) \rightarrow \mathrm{Mo}(\mathrm{d})$ and the broad overlapping features at $\sim 25000-30000 \mathrm{~cm}^{-1}$ as $\mathrm{Cl}(\pi)$ $\rightarrow \mathrm{Mo}(\mathrm{d})$. The complexity of the electronic spectra in compounds of this type is shown by a combined UV/visible absorption, MCD and DFT study of $\left.\left[\mathrm{MoOCl}_{3}\left\{\mathrm{Ph}_{2} \mathrm{P}\left(\mathrm{CH}_{2}\right)_{2} \mathrm{PPh}_{2}\right\}\right]\right]^{26}$ here we are using the spectra to confirm the presence of $\mathrm{Mo}(\mathrm{v})$ in the isolated complexes.

\section{Dimethylchalcogenides $\left(\mathrm{EMe}_{2}, \mathrm{E}=\mathrm{S}\right.$, Se, Te $)$}

Neither $\mathrm{SMe}_{2}$ or $\mathrm{SeMe}_{2}$ was found to displace thf from $\left[\mathrm{MoOCl}_{3}(\mathrm{thf})_{2}\right]$. However, reaction of a suspension of $\mathrm{MoOCl}_{3}$ in dry $\mathrm{CH}_{2} \mathrm{Cl}_{2}$ with 2 equivalents of $\mathrm{EMe}_{2}$ produced complexes with a $1: 1 \mathrm{Mo}: \mathrm{EMe}_{2}$ empirical composition, $\mathrm{MoOCl}_{3}\left(\mathrm{EMe}_{2}\right)(\mathrm{E}=\mathrm{S}$, Se). There was no evidence for the formation of the $1: 2$ $\left[\mathrm{MoOCl}_{3}\left(\mathrm{EMe}_{2}\right)_{2}\right]$ complexes. Crystals of both $\mathrm{MoOCl}_{3}\left(\mathrm{EMe}_{2}\right)(\mathrm{E}=$ $\mathrm{S}, \mathrm{Se}$ ) complexes were obtained and the structures, which are isomorphous (Fig. 4), showed them to be chloride-bridged dimers, with six-coordinate $\mathrm{Mo}(\mathrm{v})$ centres, i.e. $\left[\left\{\mathrm{MoOCl}_{2}\left(\mathrm{EMe}_{2}\right)\right\}_{2}\left(\mu-\mathrm{Cl}_{2}\right)\right]$ $(\mathrm{E}=\mathrm{S}, \mathrm{Se})$.
The $\mathrm{Mo}=\mathrm{O}$ bonds $(\sim 1.65 \AA)$ are trans to asymmetrically bound (by $\sim 0.4 \AA$ ) bridging chlorides, with the $\mathrm{EMe}_{2}$ groups arranged anti and perpendicular to the $\mathrm{Mo}_{2} \mathrm{Cl}_{4} \mathrm{O}_{2}$ plane. The geometries are very similar to those found in $\left[\left(\operatorname{MoOCl}_{2} \mathrm{~L}\right)_{2}(\mu-\right.$ $\left.\mathrm{Cl})_{2}\right]\left(\mathrm{L}=\mathrm{O}=\mathrm{C}(\mathrm{H}) \mathrm{OMe}\right.$, thf, $\left.\mathrm{O}=\mathrm{CEt}_{2}\right) \cdot{ }^{27-29}$

The reaction of $\mathrm{MoOCl}_{3}$ with $\mathrm{TeMe}_{2}$ in toluene produced brown $\left[\left\{\mathrm{MoOCl}_{2}\left(\mathrm{TeMe}_{2}\right)\right\}_{2}(\mu-\mathrm{Cl})_{2}\right]$, which is the first $\mathrm{Mo}(\mathrm{v})$ complex with a neutral tellurium donor ligand. Crystals were not obtained from this complex due to poor solubility and limited stability in solution, but spectroscopically it is very similar to the other $\mathrm{EMe}_{2}$ complexes. The failure to produce the six-coordinate monomers, $\left[\mathrm{MoOCl}_{3}\left(\mathrm{EMe}_{2}\right)_{2}\right]$, even in the presence of excess $\mathrm{EMe}_{2}$, shows that the molybdenum(v) prefers to bind a chloride from another molecule, creating the bridged dimer structure, and is consistent with the weak donor properties of the $\mathrm{EMe}_{2}$. The dimers are clearly distinguished from the $\left[\mathrm{MoOCl}_{3}\right.$ (dichalcogenoether)] monomers by their IR spectra, with the dimers showing a strong $\nu(\mathrm{Mo}=\mathrm{O})$ vibration in the range at 985-1005 $\mathrm{cm}^{-1}$ (higher frequency than in the monomeric $\left[\mathrm{MoOCl}_{3}\right.$ (dichalcogenoether)] type) and terminal Mo-Cl modes $360-310 \mathrm{~cm}^{-1}$; weaker bands in the region $\sim 270-250 \mathrm{~cm}^{-1}$ and absent in the spectra of the $\left[\mathrm{MoOCl}_{3}\right.$ (dichalcogenoether)] monomers, may be due to the chloride bridges. The magnetic moments of $\sim 1.7$ B.M./Mo confirm the $\operatorname{Mo}(\mathrm{v})$ assignment and the absence of any magnetic interactions between the molybdenum centres.

\section{Ditelluroethers}

The reaction of $o-\mathrm{C}_{6} \mathrm{H}_{4}(\mathrm{SeMe})_{2}, \quad o-\mathrm{C}_{6} \mathrm{H}_{4}(\mathrm{TeMe})_{2}$ and MeTe $\left(\mathrm{CH}_{2}\right)_{3}$ TeMe $(\mathrm{L}-\mathrm{L})$ with $\mathrm{MoOCl}_{3}$ in a $1: 1$ molar ratio in $\mathrm{CH}_{2} \mathrm{Cl}_{2}$ failed to produce the expected $\left[\mathrm{MoOCl}_{3}(\mathrm{~L}-\mathrm{L})\right]$ type complexes. Instead, dark brown complexes, identified by microanalysis as $\left[\left(\mathrm{MoOCl}_{3}\right)_{2}(\mathrm{~L}-\mathrm{L})\right]$, were obtained. Once isolated the compounds are very poorly soluble in $\mathrm{CH}_{2} \mathrm{Cl}_{2}$ and many attempts to

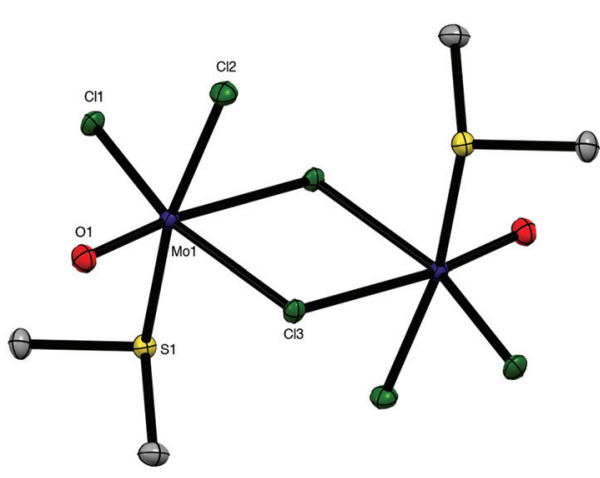

(a)

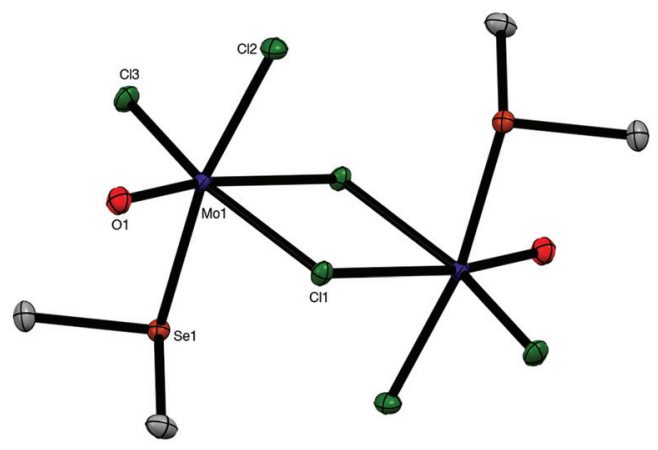

(b)

Fig. 4 Crystal structures of $\left[\left\{\mathrm{MoOCl}_{2}\left(\mathrm{SMe}_{2}\right)\right\}_{2}(\mu-\mathrm{Cl})_{2}\right]$ (a) and $\left[\left\{\mathrm{MoOCl}_{2}\left(\mathrm{SeMe}_{2}\right)\right\}_{2}(\mu-\mathrm{Cl})_{2}\right]$ (b) showing the atom numbering scheme. Ellipsoids are shown at 50\% probability and hydrogen atoms are omitted for clarity. Selected bond lengths $(\AA)$ and angles $\left({ }^{\circ}\right)$ : (a) $\mathrm{Mo1}-\mathrm{Cl}=2.3264(2), \mathrm{Mo1}-\mathrm{Cl} 2=$ 2.3341(3), Mo1-Cl3 = 2.3953(3), Mo1-Cl3' = 2.7942(2), Mo1-O1 = 1.6515(8), Mo1-S1 = 2.5537(3), Cl1-Mo1-O1 = 102.48(1), Cl2-Mo1-O1 = 102.08(3), $\mathrm{Cl} 3-\mathrm{Mo1}-\mathrm{O} 1=99.55(3), \mathrm{Cl}-\mathrm{Mo1}-\mathrm{Cl} 3=85.77(1), \mathrm{Cl} 1-\mathrm{Mo1}-\mathrm{Cl} 3=92.340(9), \mathrm{Cl} 1-\mathrm{Mo1}-\mathrm{S} 1=85.233(9), \mathrm{O} 1-\mathrm{Mo1}-\mathrm{S} 1=92.67(3), \mathrm{Cl} 3-$ $\mathrm{Mo1}-\mathrm{Cl} 3$ = 77.520(8); (b) Mo1-Cl1 = 2.4024(4), Mo1-Cl2 = 2.3385(4), Mo1-Cl3 = 2.3299(4), Mo1-Cl1' = 2.7927(4), Mo1-O1 = 1.653(1), Mo1-Se1 = 2.6647(3), $\mathrm{Cl} 1-\mathrm{Mo1}-\mathrm{O} 1=98.89(4), \mathrm{Cl} 2-\mathrm{Mo1}-\mathrm{O} 1=103.10(4), \mathrm{Cl} 3-\mathrm{Mo1}-\mathrm{O} 1=102.38(4), \mathrm{Cl} 2-\mathrm{Mo1}-\mathrm{Cl} 3=92.32(2), \mathrm{Se} 1-\mathrm{Mo1}-\mathrm{Cl} 1=78.76(1)$, Se1-Mo1-Cl1 = 87.438(10), O1-Mo1-Se1 = 92.89(4). 
produce crystals for an X-ray structure determination have been unsuccessful. However, the magnetic moments of $\sim 1.7 \mathrm{~B}$. M./Mo and the UV-visible spectra of these solids are consistent with their formulation as six-coordinate oxo-molybdenum(v) complexes.

The UV-visible spectra of the ditelluroether complexes show a d-d band at $\sim 14000 \mathrm{~cm}^{-1}\left({ }^{2} \mathrm{~B}_{2} \rightarrow{ }^{2} \mathrm{E}\right)$; a second more intense feature $18000-20000 \mathrm{~cm}^{-1}$ may be the second $\mathrm{d}-\mathrm{d}$ band $\left({ }^{2} \mathrm{~B}_{2}\right.$ $\rightarrow{ }^{2} \mathrm{~B}_{1}$ ), but given the lower electronegativity of $\mathrm{Te}^{24}$ is probably the $\mathrm{Te}(\pi) \rightarrow \mathrm{Mo}(\mathrm{d})$ charge transfer transition, which obscures the $\mathrm{d}-\mathrm{d}$ band.

The IR spectra are significantly different to those of $\left[\mathrm{MoOCl}_{3}(\mathrm{~L}-\mathrm{L})\right]\left(\mathrm{L}-\mathrm{L}=\right.$ dithioether or diphosphine), ${ }^{8,9}$ but are similar to those of $\left[\left\{\mathrm{MoOCl}_{2}\left(\mathrm{EMe}_{2}\right)\right\}_{2}(\mu-\mathrm{Cl})_{2}\right]$. In particular, the $\nu(\mathrm{Mo}=\mathrm{O})$ vibrations are at higher frequency $\left(985-1000 \mathrm{~cm}^{-1}\right)$, and in addition to several terminal $\nu(\mathrm{Mo}-\mathrm{Cl})$ modes $\sim 320-300 \mathrm{~cm}^{-1}$, also show a peak $\sim 250 \mathrm{~cm}^{-1}$, probably due to a chloride bridge. In the absence of a crystal structure, the geometries cannot be established unequivocally, but the spectroscopic data (and insolubility) are consistent with a structure type similar to those in $\left[\left\{\mathrm{MoOCl}_{2}\left(\mathrm{EMe}_{2}\right)\right\}_{2}(\mu-\mathrm{Cl})_{2}\right]$, with the $\mathrm{EMe}_{2}$ ligands replaced by bridging ditelluroethers, leading to the formulation as an oligomer, $\left[\left(\mathrm{MoOCl}_{2}\right)_{2}(\mu \text {-Cl })_{2}(\mu\right.$-ditelluroether $)]_{n}$. There are several literature examples of Group 16 ligands with $o$-phenylene backbones adopting a bridging mode, authenticated by X-ray crystal structures. ${ }^{30-32}$

The brown solution from the preparation of $\left[\left\{\mathrm{MoOCl}_{3}\right\}_{2}\{0\right.$ $\left.\left.\mathrm{C}_{6} \mathrm{H}_{4}(\mathrm{TeMe})_{2}\right\}\right]_{n}$ also deposited a few dark green crystals, which were shown by X-ray crystallographic analysis to be the mixed valence complex, $\left[\mathrm{Mo}^{\mathrm{IV}} \mathrm{Cl}\left\{o-\mathrm{C}_{6} \mathrm{H}_{4}(\mathrm{TeMe})_{2}\right\}_{2}(\mu-\mathrm{O}) \mathrm{Mo}^{\mathrm{V}} \mathrm{OCl}_{4}\right]$ (Fig. 5). This complex contains a Mo(Iv) centre coordinated to

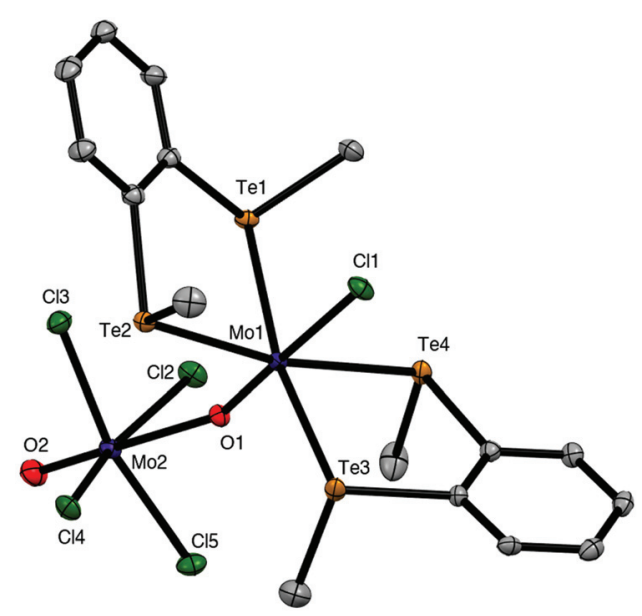

Fig. 5 Crystal structure of $\left[\mathrm{MoCl}\left\{\mathrm{O}-\mathrm{C}_{6} \mathrm{H}_{4}(\mathrm{TeMe})_{2}\right\}_{2}(\mu-\mathrm{O})\right.$ $\left.\mathrm{MoOCl}_{4}\right] \cdot \mathrm{CH}_{2} \mathrm{Cl}_{2}$ showing the atom numbering scheme. Ellipsoids are shown at $50 \%$ probability and hydrogen atoms and solvent are omitted for clarity. Selected bond lengths $(\AA)$ and angles $\left({ }^{\circ}\right)$ : Mo1-Cl1 $=2.4486(7)$, Mo2-Cl2 $-5=2.3640(7)-2.3930(7)$, Mo1-Te1 $-4=2.7432(3)-$ $2.7822(3), \mathrm{Mo1}-\mathrm{O} 1=1.704(2), \mathrm{Mo2}-\mathrm{O} 1=2.370(2), \mathrm{Mo2}-\mathrm{O} 2=1.655(2)$, $\mathrm{O} 2-\mathrm{Mo} 2-\mathrm{Cl} 2-5=78.4(1)-82.2(1), \mathrm{Te}-\mathrm{Mo1}-\mathrm{Te}_{\text {(chelate) }}=85.316(8)$, 86.185(8), Te1 $-4-$ Mo1-Cl1 = 79.647(18)-89.939(18), Cl1-Mo1-O1 = 177.91(7), Mo1-O1-Mo2 = 159.63.1(11). two chelating ditelluroethers, a terminal chloride and an $\mathrm{Mo}=\mathrm{O}$ group, which forms a very asymmetric bridge to a square pyramidal $\mathrm{MoOCl}_{4}{ }^{-}$anion, with Mo1-O1 = 1.705(4) $\AA$ and Mo2-O1 = 2.368(4) $\AA$. These bond distances may be compared with the terminal $\mathrm{Mo}=\mathrm{O}$ bond distance $(\mathrm{Mo} 2-\mathrm{O} 2=$ 1.659(5) $\AA$ ) in the latter. This complex appears to be the first structurally characterised molybdenum-ditelluroether complex in a positive formal oxidation state of the metal; all previously reported complexes are substituted carbonyls. ${ }^{33,34}$ Analogous complexes with some diphosphine and diarsine ligands have been reported, ${ }^{8,9}$ and the structure of (the previously unknown) $\left[\mathrm{MoCl}\left\{\mathrm{Me}_{2} \mathrm{P}\left(\mathrm{CH}_{2}\right)_{2} \mathrm{PMe}_{2}\right\}_{2}(\mu-\mathrm{O})\left(\mathrm{MoOCl}_{4}\right)\right]$ is discussed below. The crystals of $\left[\mathrm{Mo}^{\mathrm{IV}} \mathrm{Cl}\left\{0-\mathrm{C}_{6} \mathrm{H}_{4}(\mathrm{TeMe})_{2}\right\}_{2}(\mu-\mathrm{O})\right.$ $\left.\mathrm{Mo}^{\mathrm{V}} \mathrm{OCl}_{4}\right]$ result from a redox reaction, and its structure is not consistent with the spectroscopic data on the bulk $\left[\left\{\mathrm{MoOCl}_{3}\right\}_{2}\left\{o-\mathrm{C}_{6} \mathrm{H}_{4}(\mathrm{TeMe})_{2}\right\}\right]_{n}$. The failure to isolate mononuclear $\left[\mathrm{MoOCl}_{3}(\mathrm{~L}-\mathrm{L})\right]$ complexes with chelating $o-\mathrm{C}_{6} \mathrm{H}_{4}(\mathrm{SeMe})_{2}, o-\mathrm{C}_{6} \mathrm{H}_{4}(\mathrm{TeMe})_{2}$ and $\mathrm{MeTe}\left(\mathrm{CH}_{2}\right)_{3} \mathrm{TeMe}$, seems analogous to the case of $\left[\left\{\mathrm{MoOCl}_{2}\left(\mathrm{EMe}_{2}\right)\right\}_{2}(\mu-\mathrm{Cl})_{2}\right]$, where the $\mathrm{Mo}(\mathrm{v})$ centre prefers to form chloride bridges rather than coordinate to a second, weakly donating chalcogenenoether.

\section{Phosphine complexes}

The coordination behaviour of the chalcogenoether ligands to $\mathrm{MoOCl}_{3}$ has both significant analogies and differences to that of some phosphine ligands, making for informative comparisons. Pink or red complexes $\left[\mathrm{MoOCl}_{3}\right.$ (diphosphine)] (diphosphine $=\mathrm{Ph}_{2} \mathrm{P}\left(\mathrm{CH}_{2}\right)_{2} \mathrm{PPh}_{2}, \quad$ cis- $\mathrm{Ph}_{2} \mathrm{PCH}=\mathrm{CHPPh}_{2}$, $o-\mathrm{C}_{6} \mathrm{H}_{4}\left(\mathrm{PPh}_{2}\right)_{2}$,) were reported in the 1970 s and confirmed by IR, UV/visible spectroscopy and magnetic measurements as Mo(v) compounds. ${ }^{7-9}$ No structures were obtained, but EPR spectra supported fac octahedral isomers. ${ }^{8,9}$ A second (brown) form with $\mathrm{Ph}_{2} \mathrm{P}\left(\mathrm{CH}_{2}\right)_{2} \mathrm{PPh}_{2}$ and cis- $\mathrm{Ph}_{2} \mathrm{PCH}=\mathrm{CHPPh}_{2}$ obtained by refluxing the red form in alcohol for several hours, had similar, but not identical, spectroscopic properties; Isovitsch et al. ${ }^{10}$ confirmed the crystal structure of the red form of the $\mathrm{Ph}_{2} \mathrm{P}\left(\mathrm{CH}_{2}\right)_{2} \mathrm{PPh}_{2}$ complex as the fac isomer. In the present work we prepared the new complex $\left[\mathrm{MoOCl}_{3}\left\{\mathrm{Me}_{2} \mathrm{P}\right.\right.$ $\left.\left.\left(\mathrm{CH}_{2}\right)_{2} \mathrm{PMe}_{2}\right\}\right]$ from $\left[\mathrm{MoOCl}_{3}(\mathrm{thf})_{2}\right]$ and confirmed the fac geometry by a crystal structure (Fig. 6). The spectroscopic data on this complex (Experimental section) are in good agreement with that of the red isomers with other diphosphines. ${ }^{7-9}$ Notably, the five-membered chelate ring diphosphine complexes are fac isomers, contrasting with the mer$\left[\mathrm{MoOCl}_{3}\right.$ (dichalcogenoether)] described above.

The nature of the brown "isomers" is not entirely clear, but the original study ${ }^{8}$ of the red and brown forms of $\left[\mathrm{MoOCl}_{3}\left\{\mathrm{cis}^{-}\right.\right.$ $\left.\left.\mathrm{Ph}_{2} \mathrm{PCH}=\mathrm{CHPPh}_{2}\right\}\right]$ showed they had identical EPR spectra with coupling to equivalent phosphorus donors, i.e. were both fac forms. Hence the brown form seems likely to be the red isomer co-crystallised with a second complex, probably an EPR silent Mo(Iv) species. The presence of varying amounts of a cocrystallised second species would account for the various (small) differences reported by other workers. ${ }^{7,8,10}$ Similar problems, including X-ray structures with a variety of bond lengths for apparently the same complex, led to the proposal 


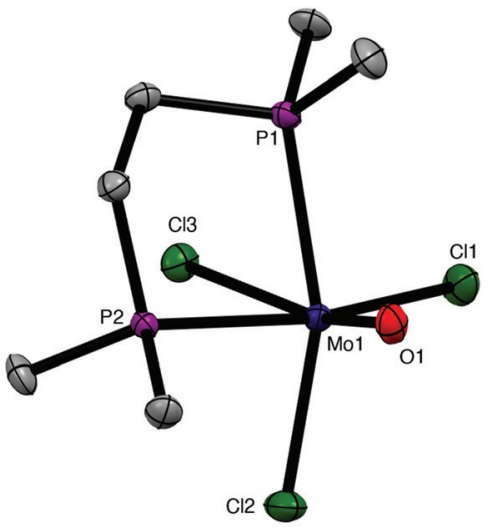

(a)

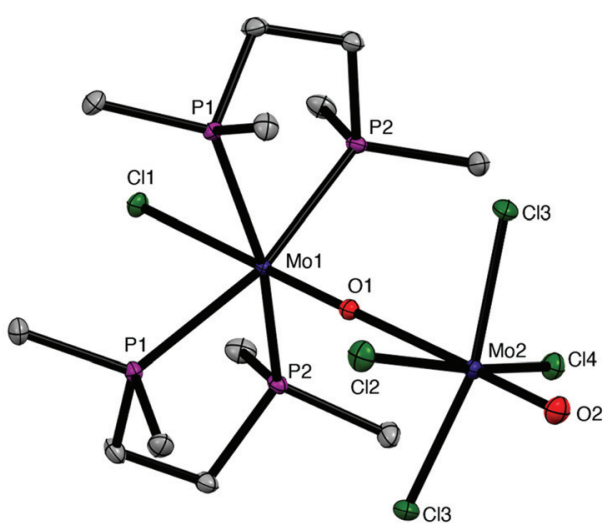

(b)

Fig. 6 Crystal structures of $\left[\mathrm{MoOCl}_{3}\left(\mathrm{Me}_{2} \mathrm{PCH}_{2} \mathrm{CH}_{2} \mathrm{PMe}_{2}\right)\right]$ (a) and $\left[\mathrm{MoCl}\left(\mathrm{Me}_{2} \mathrm{PCH}_{2} \mathrm{CH}_{2} \mathrm{PMe}_{2}\right)_{2}(\mu-\mathrm{O}) \mathrm{MoOCl}_{4}\right]$ (b) showing the atom numbering scheme. Ellipsoids are shown at 50\% probability and hydrogen atoms are omitted for clarity. Selected bond lengths $(\AA)$ and angles $\left({ }^{\circ}\right):(a)$ Mo1-Cl1 = 2.3824(9), $\mathrm{Mo1}-\mathrm{Cl} 2$ = 2.383(1), Mo1-Cl3 = 2.5011(8), Mo1-O1 = 1.680(2), Mo1-P1 = 2.5260(2), Mo1-P2 = 2.5250(8), Cl1-Mo1-Cl2 = 96.98(3), Cl1Mo1-O1 = 100.19(8), Cl2-Mo1-Cl3 = 88.76(3), Cl2-Mo1-O1 = 104.66(8), P1-Mo1-P2 = 78.84(3); (b) Mo1-Cl1 = 2.5186(2), Mo1-O1 = 1.703(4), $\mathrm{Mo1}-\mathrm{P} 1=2.5131(2), \mathrm{Mo1}-\mathrm{P} 2=2.5139(3), \mathrm{Mo2}-\mathrm{O} 1=2.394(2), \mathrm{Mo2}-\mathrm{O} 2=1.657(8), \mathrm{Mo2}-\mathrm{Cl} 2-5=2.3573(4)-2.3824(3), \mathrm{Cl} 1-\mathrm{Mo1}-\mathrm{P} 1=78.92(2)$, $\mathrm{Cl} 1-\mathrm{Mo1}-\mathrm{P} 2$ = 83.26(4), O2-Mo2-Cl2 - 5 = 97.57(2) - 98.89(4), P1-Mo1-P2 = 80.16(4), Mo1-O1-Mo2 = 178.05(8).

of bond-stretch or distortional isomerism in some other early d-block complexes, a concept subsequently considered to be erroneous. $^{35}$

Pink or purple complexes with microanalyses indicating a $\left[\mathrm{MoCl}_{2.5} \mathrm{O}\right.$ (diphosphine)] were isolated in some systems ${ }^{7-9}$ and were formulated as the ionic $\mathrm{Mo}(\mathrm{Iv})-\mathrm{Mo}(\mathrm{v})$ species $\left[\mathrm{Mo}^{\mathrm{IV}} \mathrm{OCl}\right.$ (diphosphine) $\left.)_{2}\right]\left[\mathrm{Mo}^{\mathrm{V}} \mathrm{OCl}_{4}\right]$, based upon spectroscopic data, and the observation that metathesis with $\mathrm{NaBPh}_{4}$ gave $\left[\mathrm{Mo}{ }^{\mathrm{IV}} \mathrm{OCl}\right.$ (diphosphine $\left.)_{2}\right]\left[\mathrm{BPh}_{4}\right]$.

During attempts to grow crystals of orange-yellow $\left[\mathrm{MoOCl}_{3}\left\{\mathrm{Me}_{2} \mathrm{P}\left(\mathrm{CH}_{2}\right)_{2} \mathrm{PMe}_{2}\right\}\right]$, a few deep purple crystals were also isolated that were confirmed by an X-ray structure (Fig. 6) to be $\left[\mathrm{MoCl}\left\{\mathrm{Me}_{2} \mathrm{P}\left(\mathrm{CH}_{2}\right)_{2} \mathrm{PMe}_{2}\right\}_{2}(\mu-\mathrm{O})\left(\mathrm{MoOCl}_{4}\right)\right]$, analogous to $\left[\mathrm{MoCl}\left\{\mathrm{o}-\mathrm{C}_{6} \mathrm{H}_{4}(\mathrm{TeMe})_{2}\right\}_{2}(\mu-\mathrm{O})\left(\mathrm{MoOCl}_{4}\right)\right]$ described above. Both molybdenum centres are in a distorted octahedral geometry and linked by a very asymmetric oxide bridge, Mo1-O1 = 1.703 (4), Mo2-O1 = 2.394(2) A, which may be compared with Mo2$\mathrm{O} 2=1.657(8) \AA$ for the terminal $\mathrm{Mo}=\mathrm{O}$ unit. The original formulation $^{7,8}$ was as ionic salts, $\left[\mathrm{Mo}^{\mathrm{IV}} \mathrm{OCl}\right.$ (diphosphine) $\left.)_{2}\right]\left[\mathrm{Mo}^{\mathrm{V}} \mathrm{OCl}_{4}\right]$. The reformulation as neutral $\mu$ oxido dimers in the solid state is likely to apply to all the reported examples, with the long Mo-O bond easily cleaved to give ions in solution.

Red $\mathrm{fac}$ - $\left[\mathrm{MoOCl}_{3}\left(\mathrm{PMe}_{3}\right)_{2}\right]$ was obtained by Limberg et al. ${ }^{11}$ as one product from reaction of the alkoxide complex, $\left[\mathrm{Cl}_{2} \mathrm{OMo}(\mu-\mathrm{OEt})_{2}(\mu\right.$-EtOH $\left.) \mathrm{MoOCl}_{2}\right]$ with $\mathrm{PMe}_{3}$; we obtained the same complex directly from $\left[\mathrm{MoOCl}_{3}(\text { thf })_{2}\right]$ and $\mathrm{PMe}_{3}$ in $\mathrm{CH}_{2} \mathrm{Cl}_{2}$. Our X-ray structure and the spectroscopy (Experimental section) are in good agreement with published data, ${ }^{7}$ and are not discussed further here. The interest lies in the formation of a discrete pseudo-octahedral $1: 2 \mathrm{Mo}: \mathrm{PMe}_{3}$ monomer with the strong $\sigma$-donor alkyl phosphine, which contrasts with the formation of chloride-bridged dimers,
$\left[\left\{\mathrm{MoOCl}_{2}\left(\mathrm{EMe}_{2}\right)\right\}_{2}(\mu-\mathrm{Cl})_{2}\right](\mathrm{E}=\mathrm{S}, \mathrm{Se}, \mathrm{Te})$, with the weaker donor chalcogenoethers discussed above.

\section{Experimental}

Syntheses were performed using standard Schlenk and glovebox techniques under a dry $\mathrm{N}_{2}$ atmosphere. Solvents were dried by distillation from $\mathrm{CaH}_{2}\left(\mathrm{CH}_{2} \mathrm{Cl}_{2}\right)$ or $\mathrm{Na}$ /benzophenone ketyl (toluene, n-hexane, diethyl ether). $\mathrm{MoCl}_{5}$ and $\mathrm{O}\left(\mathrm{SiMe}_{3}\right)_{2}$ were obtained from Sigma-Aldrich. The monodentate ligands $\left(\mathrm{SMe}_{2}, \mathrm{PMe}_{3}, \mathrm{SeMe}_{2}\right)$ were obtained from Sigma-Aldrich or Strem and dried over molecular sieves. $\mathrm{TeMe}_{2}$ was made by the method of Kuhn et al. ${ }^{36}$ The dithioethers, ${ }^{37}$ diselenoethers ${ }^{38,39}$ and ditelluroethers ${ }^{40,41}$ were prepared as described or by minor modifications thereof. $\mathrm{MoOCl}_{3}$ was prepared from $\mathrm{MoCl}_{5}$ and $\mathrm{O}\left(\mathrm{SiMe}_{3}\right)_{2} \cdot{ }^{42}$ and $\mathrm{MoOCl}_{4}$ obtained from Climax Molybdenum.

Infrared spectra were recorded on a PerkinElmer Spectrum 100 spectrometer in the range $4000-200 \mathrm{~cm}^{-1}$, with samples prepared as Nujol mulls between CsI plates. UV/visible spectra were recorded on powdered solids using the diffuse reflectance attachment of a PerkinElmer 750S spectrometer. Magnetic measurements were made using a Johnson Matthey magnetic balance. Microanalyses on new compounds were undertaken by London Metropolitan University or Medac Ltd.

\section{$\operatorname{mer}-\left[\mathrm{MoOCl}_{3}(\text { thf })_{2}\right]$}

Prepared following the literature method. ${ }^{43}$ Yield: $87 \%$. IR spectrum (Nujol, $v / \mathrm{cm}^{-1}$ ): $982 \mathrm{~s} \mathrm{Mo}=\mathrm{O}, 1117 \mathrm{~s}, 833 \mathrm{~s}$ br thf, $342 \mathrm{~s}, 315 \mathrm{~m} \mathrm{Mo-Cl}$. UV/Vis spectrum (diffuse reflectance) $\nu /$ $\mathrm{cm}^{-1}$ : 32 550, 26 200, 22 000, 13 250. $\mu_{\text {eff: }}$ 1.71 B.M. 


\section{fac-[MoOCl 3 \{ $\left.\left\{\mathrm{MeS}\left(\mathrm{CH}_{2}\right)_{3} \mathrm{SMe}\right\}\right]$}

Method 1. $\left[\mathrm{MoOCl}_{3}(\mathrm{thf})_{2}\right](0.150 \mathrm{~g}, 0.41 \mathrm{mmol})$ was suspended in $\mathrm{CH}_{2} \mathrm{Cl}_{2}(3 \mathrm{~mL})$ and a solution of $\mathrm{MeS}\left(\mathrm{CH}_{2}\right)_{3} \mathrm{SMe}$ $(0.056 \mathrm{~g}, 0.41 \mathrm{mmol})$ in $\mathrm{CH}_{2} \mathrm{Cl}_{2}(2 \mathrm{~mL})$ was added slowly and the solution left to stir for $1 \mathrm{~h}$. The brown solution formed was then concentrated to $3 \mathrm{~mL}$ in vacuo and the green solid which precipitated, was filtered off and dried in vacuo. Yield: $0.070 \mathrm{~g}$, $40 \%$. Required for $\mathrm{C}_{5} \mathrm{H}_{12} \mathrm{Cl}_{3} \mathrm{MoOS}_{2}$ (354.58): C, 16.94; H, 3.41. Found: C, 17.02; H, 3.39\%. IR spectrum (Nujol, v/cm ${ }^{-1}$ ): $955 \mathrm{~s}$ $\mathrm{Mo}=\mathrm{O}, 348 \mathrm{~s}, 327 \mathrm{~s}, 306 \mathrm{~m} \mathrm{Mo-Cl}$. UV/Vis spectrum (diffuse reflectance) $\nu / \mathrm{cm}^{-1}: 27400,26000,21150,18350,13700 . \mu_{\text {eff: }}$ : 1.71 B.M.

Method 2. $\mathrm{MoOCl}_{4}(0.150 \mathrm{~g}, 0.59 \mathrm{mmol})$ was suspended in toluene $(5 \mathrm{~mL})$ and a solution of $\mathrm{MeS}\left(\mathrm{CH}_{2}\right)_{3} \mathrm{SMe}(0.081 \mathrm{~g}$, $0.59 \mathrm{mmol})$ in toluene $(2 \mathrm{~mL})$ was slowly added and the green solution left to stir for $1 \mathrm{~h}$. The green solution was concentrated to $3 \mathrm{~mL}$ in vacuo to produce a green precipitate that was filtered off and dried in vacuo. The green solid was washed in hexane $(3 \times 5 \mathrm{~mL})$ and dried. Yield: $0.153 \mathrm{~g}, 70 \%$. Required for $\mathrm{C}_{5} \mathrm{H}_{12} \mathrm{Cl}_{3} \mathrm{MoOS}_{2} \cdot 0.2 \mathrm{C}_{7} \mathrm{H}_{8}$ (373.00): C, 20.61; H, 3.67. Found: C, $20.82 ; \mathrm{H}, 3.77 \%$. The complex was spectroscopically identical to that made by Method 1. Green crystals suitable for X-ray crystallography were grown from $\mathrm{CH}_{2} \mathrm{Cl}_{2}$.

\section{$\operatorname{mer}-\left[\mathrm{MoOCl}_{3}\left\{{ }^{\mathrm{i}} \operatorname{PrS}\left(\mathrm{CH}_{2}\right)_{2} \mathrm{~S}^{\mathrm{i}} \operatorname{Pr}\right\}\right]$}

$\left[\mathrm{MoOCl}_{3}\left\{{ }^{\mathrm{i}} \mathrm{PrS}\left(\mathrm{CH}_{2}\right)_{2} \mathrm{~S}{ }^{\mathrm{i}} \mathrm{Pr}\right\}\right]$ was prepared similarly to Method 1 above, and isolated as a pale green solid. Yield: $62 \%$. Required for $\mathrm{C}_{8} \mathrm{H}_{18} \mathrm{Cl}_{3} \mathrm{MoOS}_{2}$ (396.66): C, 24.22; H, 4.57. Found: C: 24.45; H, 4.15\%. IR spectrum (Nujol, $v / \mathrm{cm}^{-1}$ ): $979 \mathrm{~s} \mathrm{Mo}=\mathrm{O}$, $349 \mathrm{~s}, 312 \mathrm{~m} \mathrm{Mo-Cl}$. UV/Vis spectrum (diffuse reflectance) $\nu /$ $\mathrm{cm}^{-1}$ : 32 300, 30 400, 27 700, $23000 \mathrm{sh}, 21500 \mathrm{sh}, 13$ 600. $\mu_{\mathrm{eff}}$ : 1.69 B.M.

\section{$\operatorname{mer}-\left[\mathrm{MoOCl}_{3}\left\{\mathrm{PhS}\left(\mathrm{CH}_{2}\right)_{2} \mathrm{SPh}\right\}\right]$}

$\mathrm{MoOCl}_{3}(0.150 \mathrm{~g}, 0.69 \mathrm{mmol})$ was suspended in $\mathrm{CH}_{2} \mathrm{Cl}_{2}(3 \mathrm{~mL})$ and a solution of $\mathrm{PhS}\left(\mathrm{CH}_{2}\right)_{2} \mathrm{SPh}(0.170 \mathrm{~g}, 0.69 \mathrm{mmol})$ in $\mathrm{CH}_{2} \mathrm{Cl}_{2}(2 \mathrm{~mL})$ was added slowly and the resulting green solution left to stir for $1 \mathrm{~h}$. The resulting brown solution was concentrated to $3 \mathrm{~mL}$ in vacuo and filtered, and the orange-brown solid dried in vacuo. Yield: $0.244 \mathrm{~g}, 76 \%$. Required for $\mathrm{C}_{14} \mathrm{H}_{14} \mathrm{Cl}_{3} \mathrm{MoOS}_{2}$ (464.69): C, 36.19; H, 3.04. Found: C, 35.97; $\mathrm{H}, 3.18 \%$. IR spectrum (Nujol, $v / \mathrm{cm}^{-1}$ ): $966 \mathrm{~s} \mathrm{Mo}=\mathrm{O}, 354 \mathrm{~s}$, $319 \mathrm{~m} \mathrm{Mo-Cl}$. UV/Vis spectrum (diffuse reflectance) $\nu / \mathrm{cm}^{-1}$ : 32 200, 26 900, 22 600, 21 300, 18500 sh, 13 000. $\mu_{\text {eff: }}$ 1.71 B.M.

\section{$\left[\left\{\mathrm{MoOCl}_{2}\left(\mathrm{SMe}_{2}\right)\right\}_{2}(\mu-\mathrm{Cl})_{2}\right]$}

$\mathrm{MoOCl}_{3}(0.150 \mathrm{~g}, 0.69 \mathrm{mmol})$ was suspended in $\mathrm{CH}_{2} \mathrm{Cl}_{2}(3 \mathrm{~mL})$ and a solution of $\mathrm{SMe}_{2}(0.085 \mathrm{~g}, 1.38 \mathrm{mmol})$ in $\mathrm{CH}_{2} \mathrm{Cl}_{2}(2 \mathrm{~mL})$ was added slowly and the green solution left to stir for $1 \mathrm{~h}$. The clear green solution was then concentrated to $3 \mathrm{~mL}$ in vacuo and layered with hexane $(3 \mathrm{~mL})$. The green crystals formed were isolated via filtration and dried in vacuo. Yield: $0.73 \mathrm{~g}, 38 \%$. Required for $\mathrm{C}_{4} \mathrm{H}_{12} \mathrm{Cl}_{6} \mathrm{Mo}_{2} \mathrm{O}_{2} \mathrm{~S}_{2}$ (560.86): C, 8.57; $\mathrm{H}, 2.16$. Found: $\mathrm{C}, 8.98 ; \mathrm{H}, 2.37 \%$. IR spectrum (Nujol, $v /$ $\mathrm{cm}^{-1}$ ): $1004 \mathrm{~s} \mathrm{Mo}=\mathrm{O}, 356 \mathrm{~s}, 319 \mathrm{~s}, 268 \mathrm{~m} \mathrm{Mo-Cl}$. UV/Vis spec- trum (diffuse reflectance) $\nu / \mathrm{cm}^{-1}: 26000,22300,19600 \mathrm{sh}$, 13 800. $\mu_{\text {eff: }}$ 1.72 B.M./Mo.

\section{$\left[\left\{\mathrm{MoOCl}_{2}\left(\mathrm{SeMe}_{2}\right)\right\}_{2}(\mu-\mathrm{Cl})_{2}\right]$}

$\mathrm{MoOCl}_{3}(0.150 \mathrm{~g}, 0.69 \mathrm{mmol})$ was suspended in $\mathrm{CH}_{2} \mathrm{Cl}_{2}(3 \mathrm{~mL})$ and a solution of $\mathrm{SeMe}_{2}(0.150 \mathrm{~g}, 1.38 \mathrm{mmol})$ in $\mathrm{CH}_{2} \mathrm{Cl}_{2}(2 \mathrm{~mL})$ was slowly added and the green solution left to stir for $1 \mathrm{~h}$. The red solution formed was concentrated to $3 \mathrm{~mL}$ in vacuo and layered with hexane $(3 \mathrm{~mL})$. The dark brown crystals were isolated via filtration, and dried in vacuo. Yield: $0.154 \mathrm{~g}, 68 \%$. Required for $\mathrm{C}_{4} \mathrm{H}_{12} \mathrm{Cl}_{6} \mathrm{Mo}_{2} \mathrm{O}_{2} \mathrm{Se}_{2}$ (654.65): C, 7.34; $\mathrm{H}, 1.85 \%$. Found: C, 7.43; H, 1.93\%. IR spectrum (Nujol, v/ $\mathrm{cm}^{-1}$ ): $1004 \mathrm{~s}$ $\mathrm{Mo}=\mathrm{O}, 368 \mathrm{sh}, 351 \mathrm{~s}, 313 \mathrm{~m} \mathrm{Mo-Cl}$. UV/Vis spectrum (diffuse reflectance) $\nu / \mathrm{cm}^{-1}: 32$ 500, 26 500, $20700,14100 . \mu_{\text {eff: }} 1.68 \mathrm{~B}$. M./Mo.

\section{$\operatorname{mer}-\left[\mathrm{MoOCl}_{3}\left\{\mathrm{MeSe}\left(\mathrm{CH}_{2}\right)_{2} \mathrm{SeMe}\right\}\right]$}

$\left[\mathrm{MoOCl}_{3}(\text { thf })_{2}\right](0.150 \mathrm{~g}, 0.41 \mathrm{mmol})$ was suspended in $\mathrm{CH}_{2} \mathrm{Cl}_{2}$ (3 $\mathrm{mL})$ and a solution of $\operatorname{MeSe}\left(\mathrm{CH}_{2}\right)_{3} \mathrm{SeMe}(0.089 \mathrm{~g}$, $0.41 \mathrm{mmol})$ in $\mathrm{CH}_{2} \mathrm{Cl}_{2}(2 \mathrm{~mL})$ was added slowly and the green solution left to stir for $1 \mathrm{~h}$. The resulting brown solution was concentrated to $3 \mathrm{~mL}$ in vacuo and filtered, then the solid dried in vacuo, isolating a dark brown solid. Crystals grown from $\mathrm{CH}_{2} \mathrm{Cl}_{2}$ were dark green. Yield: $0.160 \mathrm{~g}, 90 \%$. Required for $\mathrm{C}_{4} \mathrm{H}_{10} \mathrm{Cl}_{3} \mathrm{MoOSe}_{2}$ (434.34): C, 11.06; H, 2.32. Found: C, 11.60; H, 2.50\%. IR spectrum (Nujol, $v / \mathrm{cm}^{-1}$ ): $960 \mathrm{~s} \mathrm{Mo}=\mathrm{O}$, $342 \mathrm{~s}, 310 \mathrm{~m} \mathrm{Mo-Cl}$. UV/Vis spectrum (diffuse reflectance) $\nu /$ $\mathrm{cm}^{-1}: 25$ 800, 21 500, 19 300, 14 600. $\mu_{\text {eff: }}$ 1.71 B.M.

\section{$\left[\mathrm{MoOCl}_{3}\left\{\operatorname{MeSe}\left(\mathrm{CH}_{2}\right)_{3} \mathrm{SeMe}\right\}\right]$}

$\mathrm{MoOCl}_{3}(0.150 \mathrm{~g}, 0.69 \mathrm{mmol})$ was suspended in $\mathrm{CH}_{2} \mathrm{Cl}_{2}(3 \mathrm{~mL})$ and a solution of $\operatorname{MeSe}\left(\mathrm{CH}_{2}\right)_{3} \operatorname{SeMe}(0.158 \mathrm{~g}, 0.69 \mathrm{mmol})$ in $\mathrm{CH}_{2} \mathrm{Cl}_{2}(2 \mathrm{~mL})$ was slowly added and the red/brown solution left to stir for $1 \mathrm{~h}$. The brown solution was concentrated to $3 \mathrm{~mL}$ in vacuo and filtered and the dark brown solid isolated was dried in vacuo. A deep orange-brown crystalline solid was obtained from $\mathrm{CH}_{2} \mathrm{Cl}_{2}$ solution. Yield: $0.178 \mathrm{~g}, 58 \%$. Required for $\mathrm{C}_{5} \mathrm{H}_{12} \mathrm{Cl}_{3} \mathrm{MoOSe}_{2} \cdot \mathrm{CH}_{2} \mathrm{Cl}_{2}$ (533.30): C, 13.51; $\mathrm{H}, 2.65$. Found: C, 13.96; H, 2.95\%. IR spectrum (Nujol $v / \mathrm{cm}^{-1}$ ): $954 \mathrm{~s} \mathrm{Mo}=\mathrm{O}$, $346 \mathrm{~s}$ vbr, Mo-Cl. UV/Vis spectrum (diffuse reflectance) $\nu /$ $\mathrm{cm}^{-1}$ : 32000 sh, 2700 br, 21 400, $19500,14000 . \mu_{\text {eff: }} 1.70$ B.M.

\section{$\left[\left(\mathrm{MoOCl}_{3}\right)_{2}\left\{o-\mathrm{C}_{6} \mathrm{H}_{4}(\mathrm{SeMe})_{2}\right\}\right]_{n}$}

$\mathrm{MoOCl}_{3}(0.150 \mathrm{~g}, 0.69 \mathrm{mmol})$ was suspended in dichloromethane $(3 \mathrm{~mL})$ and a solution of $o-\mathrm{C}_{6} \mathrm{H}_{4}(\mathrm{SeMe})_{2}(0.226 \mathrm{~g}$, $0.69 \mathrm{mmol})$ in dichloromethane $(2 \mathrm{~mL})$ was added slowly and the dark red/brown solution left to stir for $1 \mathrm{~h}$. The brown solution was then concentrated to $3 \mathrm{~mL}$ in vacuo, producing a brown precipitate, which was washed with $\mathrm{OEt}_{2}(3 \times 5 \mathrm{~mL})$, then the brown-pink solid was dried in vacuo. Yield: $0.170 \mathrm{~g}$, $53 \%$. Required for $\mathrm{C}_{8} \mathrm{H}_{10} \mathrm{Cl}_{6} \mathrm{Mo}_{2} \mathrm{O}_{2} \mathrm{Se}_{2}$ (700.68): C, 13.71; $\mathrm{H}$, 1.44. Found: $\mathrm{C}, 13.43 ; \mathrm{H}, 1.53 \%$. IR spectrum (Nujol, $v / \mathrm{cm}^{-1}$ ): $999 \mathrm{~s}$ br $\mathrm{Mo}=\mathrm{O}, 351 \mathrm{w}, 302 \mathrm{~s}, 292 \mathrm{sh}, 256 \mathrm{~m} \mathrm{Mo-Cl}$. UV/Vis spectrum (diffuse reflectance) $\nu / \mathrm{cm}^{-1}: 29500 \mathrm{sh}, 24900$, 20 900, 14 300. $\mu_{\text {eff: }} 1.69$ B.M./Mo. 
$\left[\left\{\mathrm{MoOCl}_{2}\left(\mathrm{TeMe}_{2}\right)\right\}_{2}(\mu-\mathrm{Cl})_{2}\right]$

$\mathrm{MoOCl}_{3}(0.150 \mathrm{~g}, 0.69 \mathrm{mmol})$ was suspended in toluene $(3 \mathrm{~mL})$ and a solution of $\mathrm{TeMe}_{2}(0.217 \mathrm{~g}, 1.38 \mathrm{mmol})$ in toluene $(2 \mathrm{~mL})$ was added slowly and the purple solution left to stir for $1 \mathrm{~h}$. The deep purple solution was concentrated to $3 \mathrm{~mL}$ in vacuo and filtered, then the dark brown solid was dried in vacuo. Yield: $0.203 \mathrm{~g}, 78 \%$. Required for $\mathrm{C}_{4} \mathrm{H}_{12} \mathrm{Cl}_{6} \mathrm{Mo}_{2} \mathrm{O}_{2} \mathrm{Te}_{2}$ (751.93): C, 6.39; H, 1.61. Found: C, 6.76; H, 2.06\%. IR spectrum (Nujol, $v / \mathrm{cm}^{-1}$ ): $985 \mathrm{~s}$ br $\mathrm{Mo}=\mathrm{O}, 327,302 \mathrm{~s}$ br, $256 \mathrm{~m}$ Mo-Cl. UV/Vis spectrum (diffuse reflectance) $\nu / \mathrm{cm}^{-1}: 34500$, 29700 sh, 27 150, 26 100, 20 900, 19 500, 14 400. $\mu_{\text {eff: }} 1.68$ B.M./ Mo.

\section{$\left[\left(\mathrm{MoOCl}_{3}\right)_{2}\left\{\operatorname{MeTe}\left(\mathrm{CH}_{2}\right)_{3} \mathrm{TeMe}\right\}\right]_{n}$}

$\mathrm{MoOCl}_{3}(0.150 \mathrm{~g}, 0.69 \mathrm{mmol})$ was suspended in dichloromethane $(3 \mathrm{~mL})$ and a solution of $\mathrm{MeTe}\left(\mathrm{CH}_{2}\right)_{3} \mathrm{TeMe}(0.217 \mathrm{~g}$, $0.69 \mathrm{mmol})$ in dichloromethane $(2 \mathrm{~mL})$ was added slowly and the brown solution left to stir for $1 \mathrm{~h}$. The brown solution was concentrated to $3 \mathrm{~mL}$ in vacuo, producing a brown precipitate which was washed with $\mathrm{OEt}_{2}(3 \times 5 \mathrm{~mL})$, then the dark brown solid was dried in vacuo. Yield: $0.322 \mathrm{~g}, 61 \%$. Required for $\mathrm{C}_{5} \mathrm{H}_{12} \mathrm{Cl}_{6} \mathrm{Mo}_{2} \mathrm{O}_{2} \mathrm{Te}_{2}$ (763.95): C, 7.86; H, 1.58. Found: C, 7.20; $\mathrm{H}, 1.38 \%$. IR spectrum (Nujol, $v / \mathrm{cm}^{-1}$ ): $988 \mathrm{~m} \mathrm{Mo}=\mathrm{O}, 303 \mathrm{~s}$, $292 \mathrm{~m}, 249 \mathrm{~m} \mathrm{Mo-Cl}$. UV/Vis spectrum (diffuse reflectance) $\nu /$ $\mathrm{cm}^{-1}$ : 26 500, 21 700, 18 600, 13 000. $\mu_{\text {eff: }}$ 1.68 B.M./Mo.

$\left[\left(\mathrm{MoOCl}_{3}\right)_{2}\left\{\boldsymbol{o}-\mathrm{C}_{6} \mathrm{H}_{4}(\mathrm{TeMe})_{2}\right\}\right]_{n}$

$\mathrm{MoOCl}_{3}(0.150 \mathrm{~g}, 0.69 \mathrm{mmol})$ was suspended in dichloromethane $(3 \mathrm{~mL})$ and a solution of $o-\mathrm{C}_{6} \mathrm{H}_{4}(\mathrm{TeMe})_{2}(0.249 \mathrm{~g}$, $0.69 \mathrm{mmol})$ in dichloromethane $(2 \mathrm{~mL})$ was added slowly and the dark brown solution left to stir for $1 \mathrm{~h}$. The brown solution was concentrated to $3 \mathrm{~mL}$ in vacuo, producing a brown precipitate which was washed with $\mathrm{OEt}_{2}(3 \times 5 \mathrm{~mL})$, and dried in vacuo. Yield: $0.285 \mathrm{~g}, 52 \%$. Required for $\mathrm{C}_{8} \mathrm{H}_{10} \mathrm{Cl}_{6} \mathrm{Mo}_{2} \mathrm{O}_{2} \mathrm{Te}_{2}$ (797.96): C, 12.04; H, 1.26. Found: C, 12.27; H, 1.43\%. IR spectrum (Nujol, $v / \mathrm{cm}^{-1}$ ): $992 \mathrm{~s}$ br $\mathrm{Mo}=\mathrm{O}, 343 \mathrm{~m}, 328 \mathrm{~m}, 302 \mathrm{~s}$, $254 \mathrm{~m} \mathrm{Mo-Cl}$. UV/Vis spectrum (diffuse reflectance) $\nu / \mathrm{cm}^{-1}$ : 32 500, 25000 sh, 21 000, 19 200, 14 500. $\mu_{\text {eff }}: 1.70$ B.M./Mo.

\section{fac- $\left[\mathrm{MoOCl}_{3}\left(\mathrm{PMe}_{3}\right)_{2}\right]$}

$\left[\mathrm{MoOCl}_{3}(\text { thf })_{2}\right](0.150 \mathrm{~g}, 0.41 \mathrm{mmol})$ was suspended in $\mathrm{CH}_{2} \mathrm{Cl}_{2}$ $(3 \mathrm{~mL})$ and a solution of $\mathrm{PMe}_{3}(0.063 \mathrm{~g}, 0.82 \mathrm{mmol})$ in $\mathrm{CH}_{2} \mathrm{Cl}_{2}$ $(3 \mathrm{~mL})$ was added slowly and the dark green solution left to stir for $1 \mathrm{~h}$. The red solution produced was then concentrated to $3 \mathrm{~mL}$ in vacuo and filtered, and the red solid dried in vacuo. Yield: $0.047 \mathrm{~g}, 31 \%$. Required for $\mathrm{C}_{6} \mathrm{H}_{18} \mathrm{Cl}_{3} \mathrm{MoOP}_{2}$ (370.45): C, 19.45; H, 4.90. Found: C, 19.28; H, 4.74\%. IR spectrum (Nujol, v/cm ${ }^{-1}$ ): $957 \mathrm{~s} \mathrm{Mo}=\mathrm{O}, 352 \mathrm{sh}, 324 \mathrm{~s}, 305 \mathrm{~m} \mathrm{Mo-Cl}$. UV/Vis spectrum (diffuse reflectance) $\nu / \mathrm{cm}^{-1}: 29600,26500,21600$, $20500 \mathrm{sh}, 15500$.

\section{fac-[MoOCl $\left.\left.3 \mathbf{M e}_{2} \mathbf{P}\left(\mathrm{CH}_{2}\right)_{2} \mathbf{P M e}_{2}\right\}\right]$}

$\left[\mathrm{MoOCl}_{3}(\text { thf })_{2}\right](0.150 \mathrm{~g}, 0.41 \mathrm{mmol})$ was suspended in $\mathrm{CH}_{2} \mathrm{Cl}_{2}$ (3 mL) and a solution of $\mathrm{Me}_{2} \mathrm{PCH}_{2} \mathrm{CH}_{2} \mathrm{PMe}_{2}(0.165 \mathrm{~g}$, $0.41 \mathrm{mmol})$ in $\mathrm{CH}_{2} \mathrm{Cl}_{2}(3 \mathrm{~mL})$ was added slowly and the solu- tion left to stir for $1 \mathrm{~h}$. The was concentrated to $3 \mathrm{~mL}$ in vacuo, filtered and then the solid was dried in vacuo. Yield: $0.131 \mathrm{~g}$, 81\%. Required for $\mathrm{C}_{6} \mathrm{H}_{16} \mathrm{Cl}_{3} \mathrm{MoOP}_{2}$ (368.44): C, 19.56; H, 4.38. Found: C, 19.83; H, 4.26\%. IR spectrum (Nujol, v/cm ${ }^{-1}$ ): $951 \mathrm{~s}$ $\mathrm{Mo}=\mathrm{O}, 362 \mathrm{~m}, 325 \mathrm{~s}, 306 \mathrm{~s} \mathrm{Mo}-\mathrm{Cl}$. UV/Vis spectrum (diffuse reflectance) $\nu / \mathrm{cm}^{-1}: 29600,26500 \mathrm{sh}, 21600,20000,15500$. $\mu_{\text {eff: }}$ 1.72 B.M.

\section{X-ray experimental}

Crystals were grown from slow evaporation of saturated solutions in $\mathrm{CH}_{2} \mathrm{Cl}_{2}$ or by liquid-liquid diffusion using $\mathrm{CH}_{2} \mathrm{Cl}_{2}$ and hexane. Data collections used a Rigaku AFC12 goniometer equipped with an enhanced sensitivity (HG) Saturn724+ detector mounted at the window of an FR-E+ SuperBright molybdenum $(\lambda=0.71073 \AA)$ rotating anode generator with VHF Varimax optics (70 micron focus) with the crystal held at $100 \mathrm{~K}$ $\left(\mathrm{N}_{2}\right.$ cryostream). Crystallographic parameters are presented in Table S1. $\dagger$ Structure solution and refinement were performed using SHELX(T)-2018/2, SHELX-2018/3 through Olex ${ }^{44}$ and were mostly straightforward. $\mathrm{H}$ atoms were added and refined with a riding model. Where additional restraints were required, details are provided in the cif file for each structure found on CCDC.

\section{Conclusions}

A range of $\mathrm{MoOCl}_{3}$ complexes with thio- and seleno-ethers have been prepared from $\left[\mathrm{MoOCl}_{3}(\text { thf })_{2}\right]$ and the ligands in anhydrous $\mathrm{CH}_{2} \mathrm{Cl}_{2}$ solution. The more weakly coordinating $\mathrm{PhS}\left(\mathrm{CH}_{2}\right)_{2} \mathrm{SPh}, \mathrm{SMe}_{2}$ and $\mathrm{SeMe}_{2}$ fail to displace the thf, but complexes of these can be obtained using a suspension of $\mathrm{MoOCl}_{3}$ in $\mathrm{CH}_{2} \mathrm{Cl}_{2}$. The reaction of $\mathrm{MoOCl}_{4}$ with dithioethers results in reduction to $\mathrm{Mo}(\mathrm{v})$ as $\left[\mathrm{MoOCl}_{3}\right.$ (dithioether)], behaviour which contrasts with that of $\mathrm{WOCl}_{4}$ or $\mathrm{WSCl}_{4}$, where either $\mathrm{W}(\mathrm{vI})$ or $\mathrm{W}(\mathrm{v})$ complexes can be obtained depending upon the reaction conditions. ${ }^{18}$ The stabilising effect of two oxido-groups on molybdenum(vi) is shown by the successful isolation of $\left[\mathrm{MoO}_{2} \mathrm{X}_{2}\right.$ (dithioether) $](\mathrm{X}=\mathrm{Cl}$ or $\mathrm{Br}) .{ }^{12,13}$ The limited affinity of the hard $\mathrm{MoOCl}_{3}$ for the weaker donor monochalcogenoethers is reflected in the formation of $1: 1$ adducts, which achieve six-coordination by forming chloride bridges, as in $\left[\left\{\mathrm{MoOCl}_{2}\left(\mathrm{E}^{\prime} \mathrm{Me}_{2}\right)\right\}_{2}(\mu-\mathrm{Cl})_{2}\right]\left(\mathrm{E}^{\prime}=\mathrm{S}\right.$, Se), rather than by coordinating a second neutral donor ligand. The same explanation accounts for the formation of oligomeric complexes, $\left[\left(\mathrm{MoOCl}_{3}\right)_{2}(\mathrm{~L}-\mathrm{L})\right]_{n}$ with $o-\mathrm{C}_{6} \mathrm{H}_{4}(\mathrm{SeMe})_{2}, o-\mathrm{C}_{6} \mathrm{H}_{4}(\mathrm{TeMe})_{2}$ and $\mathrm{MeTe}\left(\mathrm{CH}_{2}\right)_{3} \mathrm{TeMe}$, postulated to have a structure with only one chalcogen donor atom on each molybdenum, and where six-coordination is achieved via bridging chlorides and bridging dichalcogenoethers (Scheme 1). Although bridging behaviour might seem unexpected for chelates with $o-\mathrm{C}_{6} \mathrm{H}_{4}$-backbones, the presence of aryl groups makes these ligands weaker donors to hard metal centres - compare $\mathrm{PhS}\left(\mathrm{CH}_{2}\right)_{2} \mathrm{SPh}$ and ${ }^{\mathrm{i}} \mathrm{PrS}\left(\mathrm{CH}_{2}\right)_{2} \mathrm{~S}^{\mathrm{i}} \mathrm{Pr}$. There are several literature examples of $o$-phe- 
nylene-based dichalcogenoethers adopting a bridging coordination mode. ${ }^{30-32}$ The behaviour contrasts with that of $o-\mathrm{C}_{6} \mathrm{H}_{4}$ based group 15 ligands, where $O-\mathrm{C}_{6} \mathrm{H}_{4}\left(\mathrm{PMe}_{2}\right)_{2}$ or $o-\mathrm{C}_{6} \mathrm{H}_{4}\left(\mathrm{AsMe}_{2}\right)_{2}$ can produce seven- or eight-coordination in tungsten(vI) complexes, such as $\left[\mathrm{WOCl}_{4}\left\{o-\mathrm{C}_{6} \mathrm{H}_{4}\left(\mathrm{PMe}_{2}\right)_{2}\right\}\right]$ or $\left[\mathrm{WF}_{4}\left\{0-\mathrm{C}_{6} \mathrm{H}_{4}\left(\mathrm{PMe}_{2}\right)_{2}\right\}_{2}\right]^{2+} \cdot{ }^{45,46}$ The present work has also reported the first examples of $\mathrm{Mo}(\mathrm{v})$ telluroether complexes. Although the large soft tellurium centres are not usually thought to be good ligands for high valent d-block metals, a range of compounds has been reported in the last few years, including examples with $\mathrm{NbCl}_{4},{ }^{47} \mathrm{NbCl}_{5}{ }^{48}$ and $\mathrm{TaCl}_{5},{ }^{48}$ although the complexes reported here are the first examples in Group 6. Also notable is the $\mathrm{X}$-ray structural characterisation of the mixed valence $\left[\mathrm{Mo}^{\mathrm{IV}} \mathrm{Cl}\left\{0-\mathrm{C}_{6} \mathrm{H}_{4}(\mathrm{TeMe})_{2}\right\}_{2}(\mu-\mathrm{O}) \mathrm{Mo}^{\mathrm{V}} \mathrm{OCl}_{4}\right]$ and of the diphosphine analogue $\left[\mathrm{Mo}^{\mathrm{IV}} \mathrm{Cl}\left\{\mathrm{Me}_{2} \mathrm{P}\left(\mathrm{CH}_{2}\right)_{2} \mathrm{PMe}_{2}\right\}_{2}(\mu-\mathrm{O})\right.$ $\left.\left(\mathrm{MoV}^{\mathrm{V}} \mathrm{OCl}_{4}\right)\right]$; complexes of the latter type were reported in the $1970 \mathrm{~s}^{7,8}$ but this is the first structural authentication.

The work has provided detailed characterisation of $\mathrm{MoOCl}_{3}-$ chalocogenoether complexes, and comparison with the $\mathrm{W}(\mathrm{vI})$ and $\mathrm{W}(\mathrm{v})$ analogues, and lays the basis for exploration of corresponding molybdenum sulfide chloride complexes, ${ }^{19}$ which may provide single source LPCVD reagents for deposition of $\mathrm{MoS}_{2}$ thin films. The sulfide chloride systems will form the basis of future work.

\section{Conflicts of interest}

The authors have no conflicts to declare.

\section{Acknowledgements}

We thank the EPSRC for support (EP/P025137/1) and for a studentship to D. E. S. (EP/N509747/1).

\section{References}

1 E. I. Stiefel, Prog. Inorg. Chem., 1977, 22, 1.

2 E. I. Stiefel, Comprehensive Coordination Chemistry, ed. G. Wilkinson, R. D. Gillard and J. A. McCleverty, Pergamon, Oxford, 1987, ch. 36.5, pp. 1375.

3 C. D. Garner and J. M. Charnock, Comprehensive Coordination Chemistry, ed. G. Wilkinson, R. D. Gillard and J. A. McCleverty, Pergamon, Oxford, 1987, ch. 36.4, pp. 1329.

4 C. G. Young, Comprehensive Coordination Chemistry II, ed. J. A. McCleverty and T. J. Meyer, Elsevier, Oxford, 2004, vol. 4, pp. 415.

5 C. D. Garner, Comprehensive Coordination Chemistry, ed. G. Wilkinson, R. D. Gillard and J. A. McCleverty, Pergamon, Oxford, 1987, ch. 36.6, pp. 1421.

6 Molybdenum and Tungsten: Their Roles in Biological Processes, ed. A. Sigel and H. Sigel, Marcel Dekker, New York, 2002.

7 A. V. Butcher and J. Chatt, J. Chem. Soc. A, 1971, 2356.
8 W. Levason, C. A. McAuliffe and B. J. Sayle, J. Chem. Soc., Dalton Trans., 1976, 1177.

9 C. A. McAuliffe, B. J. Sayle and W. Levason, J. Chem. Soc., Dalton Trans., 1977, 2055.

10 R. A. Isovitsch, F. R. Fronczec and A. W. Maverick, Polyhedron, 1998, 17, 1617.

11 C. Limberg, M. Buechner, K. Heinze and O. Walter, Inorg. Chem., 1997, 36, 872.

12 M. D. Brown, M. B. Hursthouse, W. Levason, R. Ratnani and G. Reid, Dalton Trans., 2004, 2487.

13 M. F. Davis, W. Levason, M. E. Light, R. Ratnani, G. Reid, K. Saraswat and M. Webster, Eur. J. Inorg. Chem., 2007, 1903.

14 D. Sevdic and I. Fekete, Inorg. Chim. Acta, 1982, 57, 111.

15 C. A. McAuliffe and B. J. Sayle, Inorg. Chim. Acta, 1978, 30, 35.

16 W. Levason, C. A. McAuliffe, F. P. McCullough, S. G. Murray and C. A. Rice, Inorg. Chim. Acta, 1977, 22, 227.

17 C. A. McAuliffe and B. J. Sayle, Inorg. Chim. Acta, 1982, 64, L19.

18 D. E. Smith, V. K. Greenacre, A. L. Hector, R. Huang, W. Levason, G. Reid, F. Robinson and S. Thomas, Dalton Trans., 2020, 49, 2496.

19 V. K. Greenacre, W. Levason, G. Reid and D. E. Smith, Coord. Chem. Rev., 2020, 424, 213512.

20 S. M. Islam, K. S. Subrahmanyam, C. D. Malliakis and M. G. Kanatzidis, Chem. Mater., 2014, 26, 5151.

21 V. C. Gibson, T. P. Kee and A. Shaw, Polyhedron, 1990, 9, 2293.

22 G. W. A. Fowles, R. J. Hobson, D. A. Rice and K. J. Shanton, J. Chem. Soc., Chem. Commun., 1976, 552.

23 M. I. Larson and F. W. Moore, Inorg. Chem., 1966, 5, 801.

24 B. N. Figgis and J. Lewis, Prog. Inorg. Chem., 1967, 6, 1.

25 A. B. P. Lever, Inorganic Electronic Spectroscopy, Elsevier, Amsterdam, 1984.

26 A. Westphal, H. Broda, P. Kurz, F. Neese and F. Tuczek, Inorg. Chem., 2012, 51, 5748.

27 S. Dolci, F. Marchetti, G. Pampaloni and S. Zacchini, Eur. J. Inorg. Chem., 2013, 1371.

28 L. Favero, F. Marchetti, G. Pampaloni and S. Zacchini, Dalton Trans., 2014, 43, 495.

29 F. Marchetti, G. Pampaloni and S. Zacchini, Dalton Trans., 2013, 42, 2477.

30 J. R. Black, N. R. Champness, W. Levason and G. Reid, Inorg. Chem., 1996, 35, 1820.

31 W. Levason, S. Maheshwari, R. Ratnani, G. Reid, M. Webster and W. Zhang, Inorg. Chem., 2010, 49, 9036.

32 A. L. Hector, A. Jolleys, W. Levason and G. Reid, Dalton Trans., 2012, 41, 10988.

33 W. Levason, S. D. Orchard and G. Reid, Coord. Chem. Rev., 2002, 225, 159.

34 A. J. Barton, W. Levason and G. Reid, J. Organomet. Chem., 1999, 597, 235.

35 G. Parkin, Chem. Rev., 1993, 93, 887.

36 N. Kuhn, P. Faupel and E. Zauder, J. Organomet. Chem., 1986, 302, C4. 
37 F. R. Hartley, S. G. Murray, W. Levason, H. E. Soutter and C. A. McAuliffe, Inorg. Chim. Acta, 1979, 265, 35.

38 D. J. Gulliver, E. G. Hope, W. Levason, S. G. Murray, D. M. Potter and G. L. Marshall, J. Chem. Soc., Perkin Trans. 2, $1984,429$.

39 E. G. Hope, T. Kemmitt and W. Levason, J. Chem. Soc., Perkin Trans. 2, 1987, 487.

40 T. Kemmitt and W. Levason, Organometallics, 1989, 8, 1303.

41 E. G. Hope, T. Kemmitt and W. Levason, Organometallics, 1988, 7, 78.

42 V. C. Gibson, A. Shaw and D. N. Williams, Polyhedron, 1989, 8, 549.

43 K. Feenan and G. W. A. Fowles, Inorg. Chem., 1962, 4, 310.
44 (a) G. M. Sheldrick, Acta Crystallogr., Sect. C: Struct. Chem., 2015, 71, 3; (b) G. M. Sheldrick, Acta Crystallogr., Sect. A: Found. Crystallogr., 2008, 64, 112; (c) O. V. Dolomanov, L. J. Bourhis, R. J. Gildea, J. A. K. Howard and H. Puschmann, J. Appl. Crystallogr., 2009, 42, 339.

45 W. Levason, G. Reid, D. E. Smith and W. Zhang, Polyhedron, 2020, 179, 114372.

46 W. Levason, F. M. Monzittu, G. Reid and W. Zhang, Chem. Commun., 2018, 54, 11681.

47 Y.-P. Chang, W. Levason, M. E. Light and G. Reid, Dalton Trans., 2016, 45, 16262.

48 S. L. Benjamin, Y.-P. Chang, C. Gurnani, A. L. Hector, M. Huggon, W. Levason and G. Reid, Dalton Trans., 2014, 43, 16640 . 